\title{
CORPORATE INTEREST RATE RISK MANAGEMENT WITH DERIVATIVES IN AUSTRALIA: EMPIRICAL RESULTS*
}

LUIZ AUGUSTO FERREIRA CARNEIRO

Professor Doutor do Departamento de Contabilidade e

Atuária da Faculdade de Economia, Administração e

Contabilidade da Universidade de São Paulo - Campus Capital E-mail: luiz.carneiro@fipecafi.org
MICHAEL SHERRIS

BA, MBA, FIAA, FIA, FSA

School of Actuarial Studies

University of New South Wales - Sydney - Austrálią

E-mail:m.sherris@unswedu.au

\section{ABSTRACT}

Financial and insurance theories explain that large widely-held corporations manage corporate risks if doing so is cost-ective to reduce frictional costs such as taxes, agency costs and financial distress costs. A large number of previous empirical studies, most in the U.S., have tested the hypotheses underlying corporate risk management with financial derivative instruments. In order to quantify corporate hedge demand, most previous studies have used the ratio of principal notional amount of derivatives to company size, although they recognize that company size is not an appropriate proxy for financial risk. This paper analyzes the interest-rate-risk hedge demand by Australian companies, measured through the ratio of principal notional amount of interest rate derivatives to interest-rate-riskbearing liabilities. Modern panel data methods are used, with two panel data sets from 1998 to 2003 (1102 and 465 observations, respectively). Detailed information about interest-rate-risk exposures was available after manual data collection from financial annual reports, which was only possible due to specific reporting requirements in Australian accounting standards. Regarding the analysis of the extent of hedge, our measurement of interest-rate-risk exposures generates some significant results di erent from those found in previous studies. For example, this study shows that total leverage (total debt ratio) is not significantly important to interest-rate-risk hedge demand and that, instead, this demand is related to the specific risk exposure in the interest bearing part of the firm's liabilities. This study finds significant relations of interest-rate-risk hedge to company size, floating-interest-rate debt ratio, annual log returns, and company industry type (utilities and non-banking financial institutions).

Keywords: Interest rate risk management. Derivatives, Hedging IFRS. Panel-data estimation. JEL classification: C13, C23, G32, N27. 


\section{INTRODUCTION}

The relative importance of corporate interest-rate-risk management has been analysed by previous studies in the United States and in Australia. Bodnar et al. (1998 [9]) show the results from a survey of financial risk management by U.S. non-financial firms. About $50 \%$ of the firms in the survey state that they use derivatives. Among derivative users, $83 \%$ use derivatives to hedge foreign exchange risk, $76 \%$ use derivatives to hedge interest rate risk and $56 \%$ use derivatives to hedge commodity price risk. Therefore, the survey indicates that corporate foreign-exchange-risk hedging in the United States is relatively more important. However, a survey by Benson and Oliver (2004 [4]) shows that interest-rate-risk hedging is relatively more important to non-financial companies in Australia. In their survey, $76 \%$ of the respondents use derivatives. Among the respondents, $63 \%$ use derivatives to hedge interest rate risk, $58 \%$ use derivatives to hedge foreign exchange risk and 29\% use derivatives to hedge commodity price risk. In fact, the relative greater importance of interest rate risk in Australia must be one of the reasons why Australian accounting standards require companies to report this risk with more detail.

Bartram (2001 [2]) points out the importance of interest rate risk management for non-financial corporations. He argues that interest rate risk has direct e ects on financial assets and liabilities but that there are also indirect e ects on the value of real assets and projects. However, the fact that non-financial firms have a larger proportion of nonfinancial assets in their balance sheets makes it more di cult for them to match financial assets and liabilities, in order to achieve complete immunization. Therefore, this study recognises the importance of the interest rate risk management of non-financial companies through the risk control of interest-rate-bearing liabilities.

This paper analyzes the corporate demand for interestrate-risk management in Australia. We show that previous studies have faced data limitations in order to measure relevant variables. For example, due to limitations in the information available in financial reporting, most previous studies were not able to quantify firms' financial risk exposures. In consequence, the usual dependent variable used to measure the extent of financial hedging is the ratio of principal notional amount of derivatives to firm size. Most previous studies explicitly recognise the limitations of using this variable, but no better variable was available under the accounting standards in force at the time the data was generated. Therefore, this study builds on previous studies in the sense that it is able to measure the interest-rate-risk exposures of non-financial Australian companies.
Since 1997 Australian accounting standards require detailed reporting of companies' interest-rate-risk exposures. According to the reporting rules in force since 1997 , Australian companies are required to report the value of interest-rate-risk exposures and the extent to which these exposures are hedged with derivative financial instruments. Therefore, a manual collection of this detailed information makes it possible to measure the extent of interest-raterisk hedging with the ratio of principal notional amount of derivatives to total interest-rate-risk-bearing liabilities. As far as we are aware, this is the first empirical study to measure the risk exposure of corporate interest-rate-riskbearing liabilities. This has important implications to the empirical results, as shown in the following sections.

The two data sets used in this study cover respectively 1102 and 465 observations from 1998 to 2003. The first data set is used in a probit model to analyse the corporate decision to hedge interest rate risk. As in many previous studies, the binary dependent variable is equal to 1 if the company hedges with interest-rate derivatives and equal to 0 if otherwise. The empirical results are similar to those in previous studies, finding a significant importance of company size to the decision to hedge with derivatives. The second data set is used to analyse the extent of hedging? The analysis is done with different model specifications and by comparing the results of using two different dependent variables: 1) the ratio of principal notional amount of interest-rate derivatives to company size, which is the dependent variable used in previous studies; and 2) the ratio of principal notional amount of interest-rate derivatives to total interest-rate-risk-bearing liabilities.

The results show how some estimates are very different depending on the dependent variable used. For example, when the dependent variable is the ratio of principal notional amount of derivatives to company size the results show a significance of leverage, which is a common result in previous results using this dependent variable (for example, see Samant (1996 [46]). However, leverage is not significant if the dependent variable is the ratio of the principal notional amount of derivatives to interest-rate-risk-bearing liabilities. In this case, it is possible to notice the significant importance of the proportion of floating-interest-raterisk debt. Finally, the paper concludes that future research will benefit from more detailed hedging reporting due to the recent changes implemented by the International Financial Reporting System (IFRS), whose hedging reporting requirements became operative in January 2005.

1 We assume that firms hedge interest rate risk when they use derivatives to switchthe interest rate of their future interest payments from floating to fixed. 


\section{THEORETICAL MOTIVATIONS FOR CORPORATE RISK MANAGEMENT WITH DERIVATIVES}

For perfect, frictionless market assumptions hedging decisions have been shown to be irrelevant to the shareholders of the firm that hedges the risk. However the theoretical assumptions under which hedging is irrelevant do not hold in practice and real world hedging decisions add value to a firm under more realistic market assumptions. By relaxing the theoretical assumptions, hedging becomes important in the risk and capital management of the firm.

The classic paper of Modigliani and Miller (1958 [40] and 1963 [41]) showed that under conditions of perfect capital markets, and some other conditions ${ }^{2}$, the financial decisions of a firm are irrelevant in the sense that they do not change the total value of the firm. This follows from the fact that shareholders can reverse engineer the financing decisions of the firm on their own account at fair market prices. Corporate risk management with derivatives is part of the financial decisions of the firm, so it is also irrelevant under these conditions.

The problem of asymmetric information is approached by Mayers and Majluf (1984 [37]) in a model in which managers of the firm know more about the firm's value than potential investors. The model assumes no taxes, transaction costs or other capital market imperfections. It shows that in some cases management, if it acts on the behalf of existent shareholders, will not issue shares even if it means giving up a good investment opportunity (a positive-NPV project). That happens because the cost to existent shareholders of issuing shares at a cheap price may be higher than the return of the investment opportunity. Therefore, their model predicts that firms would prefer debt to equity if they need external funds because debt issue will not make the stock price to fall. Thus, a firm with good financial slack (large amount of cash or marketable securities, or the ability to issue riskfree debt) would undertake any positive-NPV projects, but companies facing financial distress would eventually pass up some profitable investment opportunities. Mayers and Majluf (1984 [37]) suggest that firms can build up financial slack by restricting dividends when investment expenditures are low.

Stulz (1984 [50]) points out the role of risk aversion of managers to explain corporate hedging. Stulz states that managers decide the hedging policy of the firm, but not shareholders. It is assumed that managers choose policies that maximize their expected lifetime utility given their compensation contract and their expectation of the actions shareholders or other potential investors can take to decrease their expected utility. Unlike outside stockholders, managers may not be able to fully diversify since they may hold a relatively large portion of their wealth in the firm's stock. Thus, risk averse managers will tend to engage the firm in a more active hedging policy.

Smith and Stulz (1985[49]) show that value-maximizing firms will hedge for three reasons: (1) taxes, (2) costs of financial distress, and (3) managerial risk aversion. If corporate tax expenses are a convex function of taxable income, then, by Jensen's inequality, hedging can reduce the variability of taxable income and the expected value of taxes. Smith and Stulz state that hedging can mitigate costs of financial distress by reducing expected transaction costs of bankruptcy. Also, firms may gain from increasing the price of new debt by including contractual provisions (convenants) in bond issues, which guarantee potential bondholders that firms will hedge after the sale of debt. Finally, hedging can increase firm value by reducing the compensation required by managers to bear their nondiversifiable claims on the firm. However, hedging will increase firm value only if it is cost-effective.

Breeden and Viswanathan (1998 [11]) and DeMarzo and Duffe (1995 [16]) argue that managers may hedge so as to protect their reputation as good professionals, which is assessed by the job market based on their firms' performance.

Froot et al. (1993 [23]) also suggest that firms can avoid having to pass up profitable investment opportunities through reducing variability of cash flow with financial hedging. Their rationale is that market imperfections make external financing more costly than financing with internal funds. Additionally, the marginal cost of external financing increases with the amount already raised externally. They argue that a shortfall in cash may be costly to the firm not only because of expensive outside financing, but also because of some decrease in investment. Because of the diminishing marginal returns of investment, it is necessary to reduce the level of investment in order to compensate for the more expensive external financing, whose marginal costs increase with the quantity of outside money raised. Therefore, hedging can increase the value of the firm by reducing variability in cash flows.

Schrand and Unal (1998[48]) approach the multiple sources of risk which are bundled together in a single asset or liability and which affect the distribution of firms' cash flows. For example, one single asset can be subject to many risks such as: input and output price risk; foreign exchange rate risk; interest rate risk; credit risk; liquidity risk; market risk; regulatory risk; political risk; competition risk etc. However, firms can reallocate these risks using cash market or derivative instruments. Risk reallocation is desirable because firms have a competitive advantage in bearing risks related to their activities (core-business risk) but have 
no competitive advantage in bearing most financial risks (homogeneous risk). Schrand and Unal define coordinated risk management as the process of simultaneously increasing core-business risk and decreasing homogeneous risk to achieve or maintain a target total risk level. They provide empirical evidence of this happening in the savings and loan industry by examining firms which converted from mutual to stock ownership structure. Their findings indicate that firms may use hedging not only for risk reduction, but also for reaching a risk allocation that represents the most favourable risk-return trade-off.

\section{INTEREST RATE SWAPS}

The theories above explain that cash-flow volatility is costly for the firm because of capital market imperfections. However, in the specific case of hedging interest risk with swaps, hedging can also be explained because it can lower the cost of debt financing.

Visvanathan (1998 [53]) discusses many theories that explain the use of interest rate swaps. The assumption is that companies prefer long-term fixed-rate debt, but interest rates for this type of debt are very high. Therefore, companies borrow short-term (floating-rate) debt and then use interest rate swaps to create "synthetic" longterm fixed-rate debt.

According to Flannery (1986 [19]), Diamond (1991 [17]), and Titman (1992 [51]) borrowing firms with private information on their future performance may prefer short-term debt when they expect to obtain favourable results in the short term. In fact, if results turn out to be favourable then they will be able to benefit from lower interest loans. The asymmetric information problem comes from the fact that prospective creditors may believe that companies seeking fixed-rate longterm debt may be not expecting favourable results so that the interest rate should account for a higher risk of default.

Another explanation is that creditors are subject to agency costs of debt, such as the "underinvestment" and the "risk-shifting"” problems. Wall (1989 [54]) points out that creditors would require a higher rate to compensate the higher risk of fixed-rate long-term debt.

Therefore, in both cases above firms have an incentive to issue short-term debt and then use interest rate swaps to obtain a "synthetic" long-term fixed-rate debt which has a lower interest rate than the original long-term fixedrate debt.

Important factors in interest rate hedging are: 1) the benefits of hedging for reducing the costs related to cashflow volatility (expected tax costs; costs of financial distress; agency and asymmetric information costs); 2) the benefits of interest rate hedging in reducing the cost of interest expenses; 3 ) the extent of ex-ante interest rate exposure, i.e., the relative contribution of interest rate risk to total cashflow volatility. Empirical evidence of these theories is given by Saunders (1999 [47]), for interest rate swaps. DaDalt, Gay and Nam (2002 [15]) provide empirical evidence that currency derivatives, besides interest rate derivatives, can also mitigate asymmetric information problems. They provide evidence that both the accuracy and consensus in market analyst's earnings forecasts are higher for firms that use derivatives than for those that do not.

\section{TESTABLE HYPOTHESES}

Two different dependent variables are used to measure interest rate risk hedging activity. The first dependent variable is the principal notional value of interest rate derivatives scaled by company size, which, as stated before, has been used by most previous studies on hedging demand. The choice of this dependent variable by previous researchers was mainly due to the limited information required in financial reporting by accounting standards at the time previous studies were written. The second dependent variable used aims to overcome this limitation and is based on the ratio of principal notional amounts of interest rate derivatives to total interest-rate-risk-bearing liabilities, as mentioned above. In fact, the measurement of interest rate risk exposures being hedged was only possible due to reporting requirements existing in Australia since 1997. However, this information is not available in electronic data bases and had to be collected manually from financial reports.
Table $1 \bullet$ gives details of the sample size, the company type investigated, the data source, the year the data sets refer to, the country from which companies are studied and the scope of financial instruments investigated. It can be seen that only 7 out of these 30 empirical studies were done with data sets from countries other than the United States. Regarding the demand for hedging with derivatives, four previous studies include data from Australian companies (One of the four studies, Bartram et al. ([3] 2004), covers 48 countries including Australia). However, all of these four studies were unable to measure the risk exposures being hedged, so that the dependent variable used is the principal notional amount of derivatives scales by company size.

The hypotheses tested empirically in this paper can be classified into the following groups: 1) Taxes; 2) Cost of Financial Distress; ; 3) Underinvestment Problem; 4) Economies of Scale; 5) Shareholders' value creation. 
Table 1 Previous Empirical Studies Hedging Demand

\begin{tabular}{|c|c|c|c|c|c|c|c|}
\hline Author(s & Year & Sample size & Company type & Source & Country & Year Data & Scope \\
\hline Nance et al. & 1993 & 434 & Nonfinancial & Survey & USA & 1986 & Derivatives \\
\hline $\begin{array}{l}\text { Berkman and } \\
\text { Bradbury }\end{array}$ & 1996 & 244 & Nonfinancial & Annual Reports & $\begin{array}{l}\text { New } \\
\text { Zealand }\end{array}$ & 1994 & Derivatives \\
\hline $\begin{array}{l}\text { Fenn, Post and } \\
\text { Sharpe }\end{array}$ & 1996 & 384 & Nonfinancial & $\begin{array}{l}\text { Compact } \\
\text { Disclosure and } \\
\text { Compustat }\end{array}$ & USA & 1994 & IR derivatives \\
\hline Mian & 1996 & 169 & Nonfinancial & Annual Reports & USA & 1992 & $\begin{array}{l}\mathrm{FX} \text { and IR } \\
\text { derivatives }\end{array}$ \\
\hline Samant & 1996 & 354 & $\begin{array}{l}\text { No banks or } \\
\text { utilities }\end{array}$ & $\begin{array}{l}\text { Compact } \\
\text { Disclosure and } \\
\text { Compustat }\end{array}$ & USA & $1990-91$ & IR swaps \\
\hline Tufano & 1996 & 48 & Gold Mining & Survey & USA & 1991-93 & $\begin{array}{l}\text { Commodity } \\
\text { price der. }\end{array}$ \\
\hline $\begin{array}{l}\text { Colquitt and } \\
\text { Hoyt }\end{array}$ & 1997 & 571 & Life Insurers & Annual reports & USA & $\begin{array}{l}1991 \text { or } \\
1992\end{array}$ & Derivatives \\
\hline $\begin{array}{l}\text { Fok, Carroll and } \\
\text { Chiou }\end{array}$ & 1997 & 331 & Nonfinancial & Annual Reports & USA & 1990-92 & Derivatives \\
\hline Geczy et al. & 1997 & 372 & Nonfinancial & Annual Reports & USA & 1991 & FX derivatives \\
\hline Gay and Nam & 1998 & 486 & Nonfinancial & $\begin{array}{l}\text { Swaps Monitor } \\
\text { Database }\end{array}$ & USA & 1995 & $\begin{array}{l}\text { All and IR } \\
\text { derivatives }\end{array}$ \\
\hline $\begin{array}{l}\text { Howton and } \\
\text { Perfect }\end{array}$ & 1998 & 451 & Nonfinancial & Annual Reports & USA & 1994 & $\begin{array}{l}\text { All, FX and IR } \\
\text { derivatives }\end{array}$ \\
\hline Visvanathan & 1998 & 410 & Nonfinancial & S\&P 500 reports & USA & $\begin{array}{l}1992, \\
1993\end{array}$ & IR derivatives \\
\hline Saunders & 1999 & $297-438-497$ & Nonfinancial & $\begin{array}{l}\text { Annual reports } \\
\text { - Compustat }\end{array}$ & USA & $\begin{array}{l}1991, \\
1993, \\
\text { and } 1995\end{array}$ & IR derivatives \\
\hline Haushalter & 2000 & 100 & Oil \& Gas & $\begin{array}{l}\text { Annual Reports/ } \\
\text { Survey }\end{array}$ & USA & $1992-95$ & $\begin{array}{l}\text { Commodity } \\
\text { price der. }\end{array}$ \\
\hline $\begin{array}{l}\text { Allayannis and } \\
\text { Ofek }\end{array}$ & 2001 & 724 & Nonfinancial & Annual Reports & USA & $1992-93$ & $\begin{array}{l}\text { FX deriva- } \\
\text { tives }\end{array}$ \\
\hline Cummins & 2001 & $\begin{array}{l}1216 \text { and } \\
1668\end{array}$ & Insurers & $\begin{array}{l}\text { Annual reports } \\
\text { NAIC }\end{array}$ & USA & 1994 & Derivatives \\
\hline $\begin{array}{l}\text { Hentschen and } \\
\text { Kothary }\end{array}$ & 2001 & $297-260-283$ & Nonfinancial & $\begin{array}{l}\text { Annual Reports/ } \\
\text { Compustat }\end{array}$ & USA & $\begin{array}{l}1991, \\
1992, \\
1993\end{array}$ & Derivatives \\
\hline Berkman et al. & 2002 & 158 & $\begin{array}{l}\text { Industrial and } \\
\text { mining }\end{array}$ & Survey & Australia & 1995 & $\begin{array}{l}\text { FX, IR, } \\
\text { comm. price } \\
\text { der. }\end{array}$ \\
\hline $\begin{array}{l}\text { Graham and } \\
\text { Rogers }\end{array}$ & 2002 & 442 & Nonfinancial & $\begin{array}{l}\text { SEC's EDGAR/ } \\
\text { Compustat }\end{array}$ & USA & $\begin{array}{l}1994 \text { or } \\
1995\end{array}$ & $\begin{array}{l}\mathrm{FX} \text { and } \mathrm{IR} \\
\text { derivatives }\end{array}$ \\
\hline Nguyen and Faff & 2002 & $239-230$ & nonbanking & Connect4 & Australia & $\begin{array}{l}1999- \\
2000\end{array}$ & Derivatives \\
\hline $\begin{array}{l}\text { Guay and } \\
\text { Kothary }\end{array}$ & 2003 & 234 & Nonfinancial & Compustat & USA & 1997 & $\begin{array}{l}\text { FX, IR, } \\
\text { comm. price } \\
\text { der. }\end{array}$ \\
\hline Nguyen and Faff & 2003 & $239-230$ & nonbanking & Connect4 & Australia & $1999-2000$ & Derivatives \\
\hline Bartram et al. & 2004 & $\begin{array}{l}178 \text { in } \\
\text { Australia } \\
(7309)\end{array}$ & Nonfinancial & $\begin{array}{l}\text { Thompson } \\
\text { Analytics DB } \\
\text { and Global R. }\end{array}$ & $\begin{array}{l}48 \\
\text { countries }\end{array}$ & $\begin{array}{l}2000 \text { or } \\
2001\end{array}$ & Derivatives \\
\hline Purnanandam & 2004 & 3000 & Nonfinancial & Compustat & USA & $\begin{array}{l}1996- \\
1997\end{array}$ & $\begin{array}{l}\text { FX and IR } \\
\text { derivates }\end{array}$ \\
\hline
\end{tabular}




\subsection{Taxes:}

The convexity of the effective tax function can create incentives for firms to hedge. However, the progressivity of corporate tax rates are not the only reason for the convexity of the effective tax function. Tax preference items such as tax loss carry-forwards, investment tax credits and foreign tax credits can also affect the convexity of the effective tax function [Graham and Smith (1999 [27])].

Therefore, there are two factors that can affect this convexity:

(1) The progressivity in the corporate tax rate.
(2) Tax credits (or "tax preference items") such as tax loss carry-forwards and carry-backs, investment tax credits and foreign tax credits. Because these tax credits can only be used if companies have a suffciently large pre-tax income, companies have an incentive to hedge and increase the likelihood of being able to use their tax credits as soon as possible.

Therefore, tax issues provide the following hypothesis ${ }^{4}$ in relation to corporate hedging:

Hypothesis 1 (H1): The higher the convexity of the corporate effective tax function the higher the corporate demand for hedging.

The following proxy variables will be used to test this hypothesis in this paper:
Proxy for H1:
- Future tax benefits scaled by the book value of assets.
Companies with large amounts of future tax benefits have a motivation to increase the likelihood that future pre-tax income is positive, so that they can make use of their tax credits.

The following studies use proxies to measure the effect of tax credits carried forward. Geczy et al. (1997 [25]), Graham and Rogers (2002 [26]), and Purnanandam (2004 [45]) use a similar proxy, the net operating losses (NOL) scaled by the book value of assets. Nance at al. (1993 [42]), Tufano (1996 [52]), and Visvanathan (1998 [53]) scale net operating losses by firm's market value. Two studies (Fok, Carroll and Chiou (1997 [21]) and Gay and Nam (1998 [24])) do not scale the value of net operating losses. Four other studies (Mian (1996 [39]), Berkman and Bradbury (1996 [6]), Howton and Perfect (1998 [31]), Allayanis and Ofek (2001 [1]), and Berkman et al. (2002 [5])) use a dummy value that assumes value equal to 1 when the firm has net operating losses to be carried forward and value zero otherwise.

Nance et al. (1993 [42]) argue that the benefit of hedging on expected taxes is due to the convexity of the effective tax function, so that the appropriate factor for scaling tax preference items is the firm's expected taxable income. However, proxies for expected taxable income, such as EBITDA, may assume negative value, thus generating bias. The argument here for using the book value of assets as a scaling factor is the assumption that expected taxable income and book value of assets should be proportional across firms. Any cross-section variation in this proportion should be small relative to the cross-section variation in future tax benefits.

Graham and Smith (1999 [27]) argue that the existence of NOL carry-forwards does increase the tax incentive to hedge for firms with expected profits. However, they also argue that NOL carry-forwards provide a disincentive to hedge in the case of company with expected losses, which could make the impact of NOL carry-forwards on the decision to hedge ambiguous. Graham and Rogers (2002 [26]) also point out that existent tax credits, such as NOL carryforwards, can be a proxy for financial distress, rather than a tax motivation to hedge.

\subsection{Expected Costs of Financial Distress Hypothesis}

If hedging can reduce variability of future financial results then it can also reduce the expected costs of financial distress. As explained before, these costs can be classified as both direct and indirect bankruptcy costs.

Therefore, expected costs of financial distress provide the following hypothesis in relation to corporate hedging: 
Hypothesis 2 (H2): The higher the expected costs of financial distress the higher the corporate demand for hedging.

It is important to recognise two components of a company's expected costs of financial distress: 1) the extent of the exposure to financial risk; 2 ) the probability of adverse financial outcomes. Therefore, proxy variables used to test this hypothesis should be able to take these two components into account.

For example, if a company has a high financial leverage then the extent of its expected costs of financial distress will depend not only on the size of debt but also on the variability of total debt. Although leverage is a relevant proxy for expected financial distress costs, ideally one should also be able to measure other factors that could influence these costs. In fact, some of these factors can be diffcult to measure, for example: company's risk appetite, operational risk, regulatory risk, competition risk, regulatory risk, and political risk. Also, at the empirical research level, it is diffcult to quantify important factors such as correlations between assets and liabilities. These correlations are important to provide a measure of total financial risk.

Therefore, despite the fact that financial leverage is generally accepted as a proxy for total financial risk, one should, where possible, quantify the original sources of financial risk and how they relate to each other. An example is the case in which a company has a "not so high" debt-to-equity ratio but there is much mismatch between assets and liabilities. In this case there is also a high expected cost of financial distress due to the high probability that the payment of liabilities will not be honoured.

The level of debt risk also has to be considered. For instance, a company could have a "not so high" debt-to-equity ratio but most of its debt could be very uncertain, e.g., all of the debt could be indexed to a floating interest rate. Here the probability of financial distress is high despite the fact that leverage is not so high.

Finally, one should ensure that leverage is measured before the company hedges, so that it reflects the company's ex ante financial risk. For example, in the case of insurers, leverage is affected after reinsurance is contracted, since there is a reduction in the outstanding claims reserve.

The following proxy variable will be used to test hypothesis $2(\mathrm{H} 2)$ in paper:

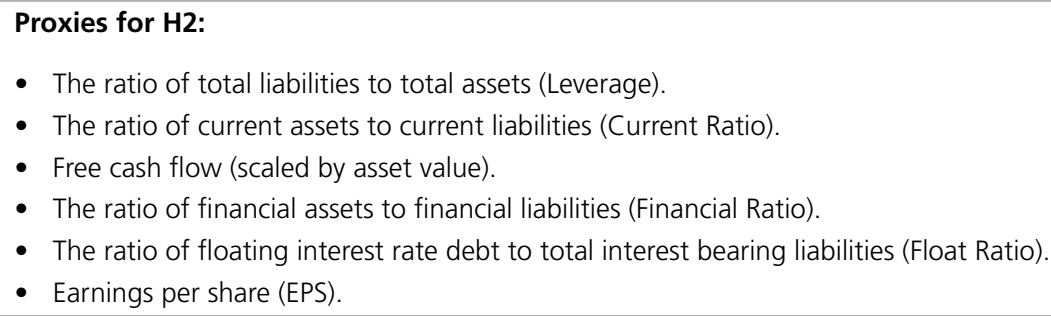

All previous studies use some measure of financial leverage as a proxy for a firm's financial distress. This study measures leverage by the ratio of total liabilities to total assets, as also used by Graham and Rogers (2002 [26]), Nguyen and Faff (2002 [43]), Bartram et al. (2004 [3]), and Purnanandam (2004 [45]). Other studies use proxies such as the ratio of capital to debt or the ratio of debt to equity.

The current ratio is used as a measure of financial liquidity and is equal to the ratio of current assets to current liabilities. It measures the firm's ability to honour its liabilities in the short run. This same liquidity measure was use by Nance et al. (1993 [42]), Mian (1996 [39]), Fok et al. (1997 [21]), and Nguyen and Faff (2002 [43]).

Free cash-flow is used as a proxy for financial distress/strength and equals the operational cash flow minus capital expendi- ture and dividends. It is a measure of a firm's liquidity after the firm has paid for everything, including investments. For example, Saunders (1999 [47]) also free cash flow to measure liquidity and test the asset substitution hypothesis. Some previous studies classify liquidity as a "hedging substitute", instead of associating it directly to financial distress. This is in line with the argument by Froot, Scharfstein and Stein (1993[23]) that external financing is costlier than internal financing. Therefore, it can be argued that less liquid firms have a smaller financial buffer and should then be more likely to hedge with derivatives. However, it is only true if we observe ex-ante liquidity. It is expected that after firms hedge they may obtain a higher level of (ex-post) liquidity. Because the data used in this paper contains only ex-post liquidity, the hypothesis here is that higher liquidity is related to more interest-rate-risk hedge ${ }^{5}$.

\footnotetext{
5 It is important to consider that derivatives are off-balance-sheet financial instruments, so they do not directly affect balance-sheet accounts. For example, interest-rate-risk hedging can change the firm's debt composition (the floating-to-fix mix) without changing the value of total debt. Therefore, with the exception of "free cash flow", the other proxy variables for hypothesis 2 can be considered as ex-ante proxy variables.
} 
Financial reports from Australian companies provide enough detail about financial assets and liabilities ${ }^{6}$. This study also uses the ratio of financial assets to financial liabilities (Financial Ratio) to measure the firm's financial strength. This proxy was not found in previous studies. Because interest rate is a financial risk, it makes sense to use a measure of financial strength based on financial assets and liabilities.

Because this study aims to analyse the corporate demand for interest rate hedging, it is important to use an explanatory variable which proxies for interest rate risk exposure. We use the ratio of floating interest rate to total interest-rate-riskbearing liabilities. Graham and Rogers (2002 [26]) also use a similar explanatory variable, the sum of debt in current liabilities plus long-term floating debt, scaled by total debt.

Earnings per share (EPS) equal the net profit after tax, less outside equity interests and preference dividends divided by diluted weighted number of shares outstand- ing during the year. Again, some previous studies classify dividend payout as a "hedging substitute" item. However, the hypothesis here is that a higher dividend payout decreases the chance that funds will be available to pay fixed liabilities. Dividend policy can also be a proxy for growth opportunities, but this problem is overcome with the use of a specific proxy (research and development expenditure - RED).

\subsection{Underinvestment Cost Hypothesis}

Financially distressed firms may reject positive NPV projects because the benefits would accrue mainly to bondholders at the shareholders' expense. Therefore, hedging can mitigate the agency cost of underinvestment through reduction of the probability of future financial distress.

Theory indicates that the underinvestment problem is greatest for leveraged firms which have significant growth options in their investment set. This implies the following hypothesis:

Hypothesis 3 (H3): The higher the growth opportunities of the leveraged firm the higher the corporate demand for hedging.

The following proxy for growth opportunities is used:

Proxies for H3:

- Research and development expenditure (R\&D) scaled by total assets.

Many previous empirical studies also use RED expenses to test the underinvestment motivation to hedge (NANCE et al., (1993 [42]), FOK et al., (1997 [21]), GECZY et al., (1997 [25]), GAY; NAM, (1998 [24]), HOWTON; PERFECT, (1998 [31]), ALLAYANNIS; OFEK, (2001 [1]), GRAHAM; ROGERS, (2002 [26]); PURNANANDAM, (2004 [45])). Another common proxy variable used in previous studies is the market-to-book ratio. However, while most previous studies found statistically significant results for RED, most results using the market-to-book ratio were insignificant or the sign of the estimated coefficient was different than expected. One possible reason for this is the diffculty in measuring the firm's book value, used in the market-to-book ratio calculation. For example, it is diffcult to value a firm's intangible assets. Similarly, existing fixed assets are also diffcult to value unless a market for used equipment exists. For these reasons, the proxy for growth opportunities in this study is only based on RED.

\subsection{Scale Economies Hypothesis}

Firm size is a proxy for many factors that impact the corporate demand for hedging. Yet, there is much controversy about the relation between these factors and firm size. For example, it is argued that even small bankruptcy costs can be suffcient to induce large firms to hedge, if the reduction in expected bankruptcy costs exceeds the costs of hedging. However, Warner (1977 [55]) finds that bankruptcy costs are less than proportional to firm size, so that the reductions in expected bankruptcy costs are greater for small firms, which, for this reason, should be more likely to hedge. In the case of reinsurance, Mayers and Smith (1990 [38]) argue that bankruptcy costs should have a higher impact on smaller firms, and that small firms are less likely to have the "specialized internal talent" available in larger firms, so that they would tend to reinsure more. Nance et al. (1993 [42]) argue that smaller US firms are more likely to have taxable income in the progressive region of the tax schedule, again implying that they are more likely to hedge.

6 Financial assets include for example cash, receivables, and investment accounted for using the equity method. Financial liabilities include payables and bank overdrafts and loans. Financial assets and liabilities are also classified in three categories related to interest rate: floating interest, fixed interest rate, and non-interest bearing. 
Cummins et al. (2001 [14]) also argue that larger insurers may be more diversified and therefore would demand less additional risk management instruments.

However, on the other side, Block and Gallagher (1986 [7]) and Booth, Smith and Stulz (1984 [10]) argue that hedging programs exhibit informational scale economies and that larger firms are more likely to hedge. Also, in the case of derivative markets, there are significant scale economies in the structure of transaction costs, implying that large firms are more likely to hedge with these instruments. Thus, despite the fact that most empirical results show a significant relation between hedging and company size, it is argued that the relation between hedging and firm size is theoretically undetermined.

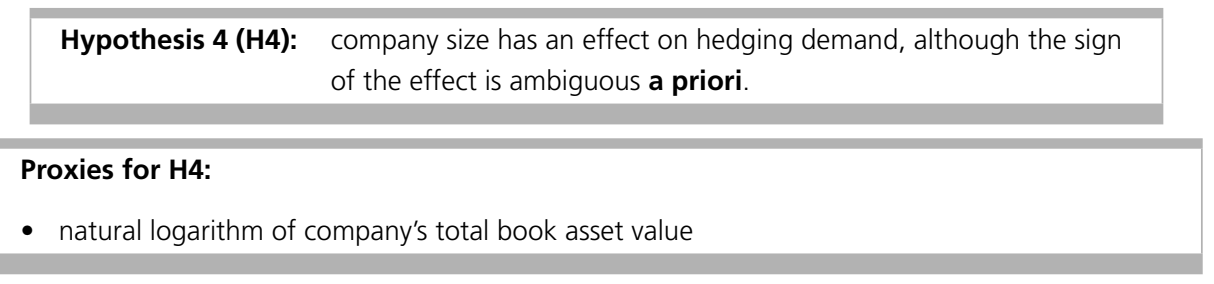

Almost all previous empirical studies also use some proxy for company size. Like many previous studies (Allayannis and Ofek (2001 [1]), Graham and Rogers (2002 [26]), Guay and Kothary (2003 [28]), Nguyen and Faff (2003 [44]), and Bartram et al.(2004 [3])), this study uses the natural logarithm of total assets. Instead, Fok et al. (1997 [21]) and Saunders (1999 [47]) use the total value of assets to proxy company size. Most other empirical studies measure company size by using the market value of equity plus the book value of debt.

\subsection{Corporate Hedging and Shareholder's Value Creation}

Risk management at the firm level is only economically feasible if the increase in firm value is greater then the hedging costs, and if shareholders cannot benefit from a similar increase in value by managing risk on their own account at a lower cost. Therefore, if firms hedge, it is expected that hedging is being used to increase firm value through reduction in taxes, costs of financial distress and agency costs. Therefore, the following hypothesis is assumed:

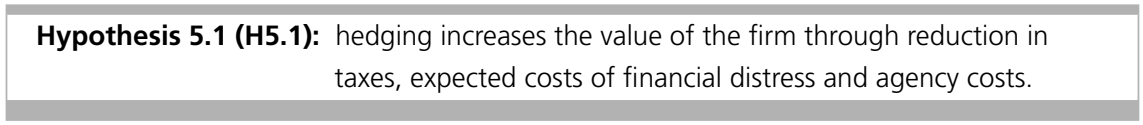

There are many variables that could be used to measure the increase in firm value, such as return on investment $(\mathrm{ROI})$, return on assets $(\mathrm{ROA})$, economic and market value added (EVA and MVA), Tobin's Q, price-earnings ratio, and stock price return. This study uses the annual log return in stock prices to proxy the increase in firm value. The rationale is that more interest-rate-risk hedging is associated with higher annual increase in share price.

\section{Proxy for H5.1: \\ - annual log return in share price.}

Finally, Table 20 summarizes the hypotheses to be tested and the expected estimation results in this paper.
Table 2 Hypotheses Tested on Corporate Hedging

\begin{tabular}{l|c|c}
\multicolumn{1}{c|}{ Explanatory Variable } & Hypothesis & Expected Sign \\
Future Tax Benefit & $\mathrm{H} 1$ & $(+)$ \\
\hline Leverage & $\mathrm{H} 2$ & $(+)$ \\
\hline Financial Ratio & $\mathrm{H} 2$ & $(-)$ \\
\hline Float Ratio & $\mathrm{H} 2$ & $(+)$ \\
\hline Current Ratio & $\mathrm{H} 2$ & $(-)$ \\
\hline Free Cash Flow & $\mathrm{H} 2$ & $(-)$ \\
\hline Earnings per Share (EPS) & $\mathrm{H} 2$ & $(+)$ \\
\hline D\&E & $\mathrm{H} 3$ & $(+)$ \\
\hline Ln Assets & $\mathrm{H} 4$ & $(+/-)$ \\
\hline Ln Returns & $\mathrm{H} 5$ & $(+)$
\end{tabular}




\section{PREVIOUS STUDIES AND DATA AVAILABILITY}

When mentioning the previous empirical studies on interest-rate-risk hedging, it is important to take into account the accounting standards in force at the time the studies were written. In fact, despite the substantial improvements in hedging reporting, the accounting standards in the U.S. in the 1990s imposed some limitations to empirical work. An important limitation was the unavailability of quantified financial risk exposures. With this, the principal notional amount of derivatives (scaled by company size) was the most used proxy for hedging activity in previous studies. Fortunately, since 1997 the Australian accounting standards require detailed information on interest risk exposures of Australian corporations and on the hedging instruments used to manage these exposures. Because of this, this study is able to show the improvements in empirical analysis that are possible when one is able to quantify the exposures being hedged.

Since January 2005, many countries, including Australia, have adopted the accounting standards issued by the International Accounting Standard Board (IASB). Therefore, these countries will benefit from a standardized International Financial Report System (IFRS). With regards to the financial reporting of derivative financial instruments, the IFRS follows the developments of standards previously required by accounting boards in many countries, such as the Financial Accounting Standard Board (FASB) in the US and the Australian Accounting Standard Board (AASB) in Australia. Although the US did not fully adopt the IFRS in 2005, the FASB and the IASB have been working in the convergence of their accounting standards since 2002, so that the remaining differences are expected to be overcome soon.

Most previous studies on the corporate demand for hedging with derivatives are based on reported data from US companies in the 1990s, when disclosure of derivative financial instruments became compulsory. However, the extent of informational disclosure on derivatives differed substantially in the US and in Australia until the convergence of accounting standards in January 2005.

In particular, since 1997 Australian companies have started to report more detailed information about the hedging of interest rate risk with derivatives. An important difference from the US reporting requirements was that Australian companies had to report interest rate risk expo- sures, measured by interest-raterisk-bearing item, besides the notional amount of derivatives used. Since 1990 the FASB had required US companies to report the notional amounts of derivatives used, but not the value of hedged items. Graham and Rogers (2002[26]) state that Current financial reporting guidelines do not require firms to disclose the underlying asset and/or liability that is being hedged with a derivative contract. Thus, most previous studies based on US companies could not measure ex-ante risk exposures directly, so that the "hedge ratio" could also not be precisely calculated. In fact, the FASB only made the reporting of financial risk exposures compulsory since December 2000, with FASB Statement No. 133.

This fact explains why most previous empirical studies on the corporate demand for hedging with derivatives by US companies were based primarily on the notional amount of derivatives scaled by company size. In fact, this was the best proxy available for hedging activity at the time they were written. Exceptions to this are previous studies based on the commodity price hedging in the gold industry (Tufano (1996 [52])) and in the oil and gas industry (Haushalter (2000 [29]) and Lookman (2004 [36])), in which proxies for the hedge ratio are built based on the level of expected future production. However, for these proxies to be appropriate, the level of production must be close to the level of sales (the sales revenue is the hedged item). Furthermore, these previous studies on commodity price risk provide results that cannot be generalized to all companies since they refer to risks specific to the gold mining and the oil and gas industries. More general results are obtained with studies on foreign exchange risk or interest risk, since they are common in all types of companies.

Table $3-$ shows previous studies on hedging with derivatives since 1993. The table shows the authors' names; the year of publication; the data source, the time range and the country from which data was collected; and the dependent variable used in the studies. It can be seen that, with the exception of Haushalter (2000 [29]) and Lookman (2004[36]), all other previous studies used the ratio of notional value of derivatives to asset value as a proxy to the hedge ratio.

\section{ACCOUNTING STANDARDS IN THE US}

Table $4 \bullet$ lists the FASB Accounting Standards that affected the reporting of corporate risk management with derivatives until the adoption of the IFRS in 2005.

The FASB Statement No. 105 was a product of the first phase on disclosure of information about financial instruments in the US. With this statement, in 1990 US companies were required to report notional principal amounts of financial instruments with off-balance-sheet risk (i.e., the risk of accounting loss for financial instruments that exceeds the amounts reported on the balance sheet) and concentrations of credit risk (e.g., the maximum amount of exposure on such financial instruments should any party to the agreement fail to perform his or her duties). This standard applied primarily to swap contracts and required disclosure of the face or contract amount and the nature and terms of the instrument. 
Table 3 | Previous Studies on Corporate Hedging: Data and Proxies Used

\begin{tabular}{|c|c|c|c|c|}
\hline Author(s) & Date & Source of Data & Country & Dependent Variable \\
\hline Nance et al. [42] & 1993 & Survey (1996) & USA & Binary: hedgers / non hedgers \\
\hline Mian [39] & 1996 & Annual Reports (1992) & USA & Binary: hedgers / non hedgers \\
\hline Berkman and Bradbury [6] & 1996 & Annual Reports (1994) & $\begin{array}{c}\text { New } \\
\text { Zealand }\end{array}$ & Notional value of derivatives / assets \\
\hline Tufano [52] & 1996 & Survey (1991-93) & USA & $\begin{array}{l}\text { Notional value of derivatives / gold price } \\
\text { exposure }\end{array}$ \\
\hline Samant [46] & 1996 & Annual Reports (1990-92) & USA & $\begin{array}{l}\text { Binary: hedgers / non hedgers and notio- } \\
\text { nal value / assets }\end{array}$ \\
\hline Fenn, Post and Sharpe [20] & 1996 & Annual Reports (1995) & USA & Notional value of derivatives / assets \\
\hline Colquitt and Hoyt [12] & 1997 & Annual Reports NAIC (1992) & USA & $\begin{array}{l}\text { Binary: hedgers / non hedgers Notional } \\
\text { value / assets }\end{array}$ \\
\hline Fok, Carroll and Chiou [21] & 1997 & Annual Reports (1990-92) & USA & Binary: hedgers / non hedgers \\
\hline Geczy et al. [25] & 1997 & Annual Reports (1991) & USA & Binary: hedgers / non hedgers \\
\hline Gay and Nam [24] & 1998 & Proxy statement (1995) & USA & Notional value of derivatives / Assets \\
\hline Howton and Perfect [31] & 1998 & Annual Reports (1994) & USA & $\begin{array}{l}\text { Notional value of Derivatives / market } \\
\text { value of equity }\end{array}$ \\
\hline Visvanathan [53] & 1998 & Annual Reports (1992-93) & USA & Binary: IR derivatives users and non-users. \\
\hline Saunders [47] & 1999 & $\begin{array}{l}\text { Annual Reports }(1991,1993 \text {, and } \\
\text { 1995) }\end{array}$ & USA & Binary: hedgers / non hedgers \\
\hline Haushalter [29] & 2000 & $\begin{array}{l}\text { Annual Reports (1992-1994) } \\
\text { Survey (1995) }\end{array}$ & USA & $\begin{array}{l}\text { Percentage of oil and gas production } \\
\text { hedged }\end{array}$ \\
\hline Allayannis and Ofek [1] & 2001 & Annual Reports (1992-93) & USA & $\begin{array}{l}\text { Binary: hedgers / non hedgers; notional } \\
\text { value / assets }\end{array}$ \\
\hline Cummins et al. [14] & 2001 & Annual Reports (1994) & USA & Volume of derivative transactions / assets \\
\hline Hentschel and Kothari [30] & 2001 & Annual Reports (1991-1993) & USA & Standard deviation of daily equity returns \\
\hline Berkman et al. [5] & 2002 & Survey (1995) & Australia & Binary: hedgers / non hedgers \\
\hline Graham and Rogers [26] & 2002 & Annual Reports (1994-95) & USA & Net notional value of derivatives /assets \\
\hline Nguyen and Faff [43] & 2002 & Annual Report (1999 and 2000) & Australia & $\begin{array}{l}\text { Binary: hedgers / non hedgers; notional } \\
\text { value / Assets }\end{array}$ \\
\hline Guay and Kothary [28] & 2003 & Annual Reports (1997) & USA & Notional Value of derivatives / assets \\
\hline Nguyen and Faff [44] & 2003 & Annual Report (1999 and 2000) & Australia & Notional Value of Derivatives/Assets \\
\hline Bartram et al. [3] & 2004 & Annual Reports (2000 or 2001) & $\begin{array}{c}48 \\
\text { countries }\end{array}$ & Binary: hedgers / non hedgers \\
\hline Purnanandam [45] & 2004 & Annual Reports (1996-1997) & USA & Notional value of derivatives / assets \\
\hline
\end{tabular}

Table $4 \quad$ FASB Statements and Hedging Reporting

\begin{tabular}{c|l|c|c}
$\begin{array}{c}\text { FASB } \\
\begin{array}{c}\text { Statement } \\
\text { No. }\end{array}\end{array}$ & \multicolumn{1}{|c|}{ Statement Title } & Issued Date & Operative Date \\
\hline FAS 105 & $\begin{array}{l}\text { Disclosure of Information about Financial Instruments with Off-Balance-Sheet } \\
\text { Risk and Financial Instruments with Concentrations of Credit Risk }\end{array}$ & 1990 Mar & 1990 Jun \\
\hline FAS 107 & Disclosures about Fair Value of Financial Instruments & 1991 Dec & 1992 Dec \\
\hline FAS 119 & $\begin{array}{l}\text { Disclosure about Derivative Financial Instruments and Fair Value of Financial } \\
\text { Instruments }\end{array}$ & 1994 Oct & 1994 Dec \\
\hline FAS 133 & Accounting for Derivative Instruments and Hedging Activities & 1998 Jun & $\begin{array}{c}1999 \text { Jun (deferred } \\
\text { to 2000 Jun) }\end{array}$ \\
\hline FAS 138 & $\begin{array}{l}\text { Accounting for Certain Derivative Instruments and Certain Hedging Activi- } \\
\text { ties-an amendment of FASB Statement No. 133 }\end{array}$ & 2000 Jun & 2000 Jun \\
\hline FAS 149 & $\begin{array}{l}\text { Amendment of Statement 133 on Derivative Instruments and Hedging } \\
\text { Activities }\end{array}$ & 2003 Apr & 2003 Jun
\end{tabular}


Since December 1992, the FASB Statement No. 107 required entities to disclose the fair value of financial instruments, both assets and liabilities recognized and not recognized in the statement of financial position. Therefore, with this statement the fair value of derivative financial instruments had to be reported.

However, the data sets available in the U.S. in the early 1990s imposed some limitations on empirical analysis. Hentschel and Kothari (2001 [30] p.117) analyse the use of derivatives with a sample of US corporation from 1991 to 1993. In their conclusions they comment that Our data show the considerable limitations of the derivatives disclosures under the current US accounting standards. Firms do not have to disclose the sign or the magnitude of their derivative exposures, only the notional principal of their positions. (...) The crudeness of the information makes it diffcult to determine whether an individual firm is reducing or taking risks with derivatives.

Since December 1994, the FASB Statement No. 119 required disclosure of amounts, nature, and terms of derivative financial instruments that were not subject to FASB Statement No. 105 because they did not result in off-balancesheet risk of accounting loss. It was applicable to derivative financial instruments such as futures, forwards, swaps, option contracts and other financial instruments with similar characteristics. Also, for the first time this standard required a distinction to be made between financial instruments held or issued for trading purposes and financial instruments held or issued for purposes other then trading.

We can notice from Table 3 that the first empirical studies tested the decision to hedge or not to hedge with derivatives (FRANCIS; STEPHAN, (1993 [22]); NANCE; SMITH; SMITHSON, (1993 [42]); DOLDE, (1995 [18]); WYSOCKI, (1996 [56]); MIAN, (1996 [39]); COLQUITT; HOYT, (1997 [12]); FOK; CARROLL; CHIOU, (1997 [21]); GCZY; MINTON; SCHRAND, (1997 [25]). These studies classified companies between hedgers and non-hedgers, built a binary dependent variable, and then used a probit/ logit econometric model to test the decision to hedge.

Since December 2000, FASB Statement No. 133 required more detailed information on the fair value of assets and liabilities involved in the corporate risk management activities. This time, disclosures applied in determining the fair value of a financial instrument, with detailed information required not only for derivative instruments, but also for the hedged items. Therefore, this statement required the identification of the hedging instrument, the hedged item, the nature of the risk being hedged, and how the hedging instrument's effectiveness in offsetting the exposure to changes in the hedged item's fair value attributable to the hedged risk was assessed. Despite the data availability on hedged items since FASB Statement No. 133, Table 3 shows that the most recent studies in the US did not make use of this type of information. Lastly, the FASB Statements No. 138 and 194 amended and clarified the reporting structure defined in the Statement No. 133.

\section{ACCOUNTING STANDARDS IN AUSTRALIA}

Regarding the Australian reporting standards, the first requirements of financial reporting of derivatives instruments appeared in the Australian Accounting Standard 33 (AAS 33, and AASB 1033) in December 1996. The AASB 1034 , also issued at that time, defined the more general requirements for the financial reports. Both AAS 33 and AASB 1034 were amended by their then new versions in 1999 (See Table 5 O).

Although AAS 33 did not require very detailed information on derivative instruments in general (if we compare with the equivalent requirements made at that time by the FASB in the US), this accounting statement did require enough detailed information about interest rate risk exposures and their management with derivatives.
Since December 1997, Australian companies had to show in their annual reports their interest rate risk exposures and hedges by class of asset and liability. These classes are: 1) floating interest rate risk bearing; 2) fixed interest rate risk bearing; and non-interest rate risk bearing (e.g., payments to trade creditors).

Therefore, with quantified interest rate risk exposures, by class of liability, and the corresponding notional principal amounts of derivatives used, it is possible to measure ex-ante interest rate risk exposure and the extent of expost hedging positions of Australian companies.

An important thing is that it was possible to first identify whether companies were actually subject to interest rate risk because they had to report interest rate risk expo-

Table 5 || AASB Statements and Hedging Reporting

\begin{tabular}{l|l|c|c} 
Statement No. & Statement Title & Issued Date & Operative Date \\
AASB 1034 (1996) & Information to Be Disclosed in Financial Reports & 1996 Dec & 199730 June \\
\hline AASB 1033 and AAS 33 (1996) & Presentation and Disclosure of Financial Instruments & 1996 Dec & 199731 Dec \\
\hline AASB 1034 (1999) & Financial Report Presentation and Disclosures & 1999 Oct & 200130 June \\
\hline AASB 1033 and AAS 33 (1999) & Presentation and Disclosure of Financial Instruments & 1999 Oct
\end{tabular}


sures even if they did not hedge these risks. Therefore, the classification of companies between hedgers and no-hedgers is more accurate.

Additionally, Statement AAS 33 required entities to state the objectives for holding or issuing derivative financial instruments, the context needed to understand those objectives, and their strategies for achieving those objectives. Therefore, this requirement made it possible to verify whether companies were using derivatives and if their reasons for using derivatives were for hedging or trading purposes. A significant number of companies report their interest rate risk exposures together with the principal notional value of derivatives used to hedge them, which makes it possible to measure the size of hedges.

\section{THE IFRS AND THE REPORTING OF HEDGING}

Since 1 January 2005, the Australian equivalent of IFRS has been fully implemented through accounting standards AASB 101-141. It is a requirement that all reporting entities in Australia adopt the standards as they have replaced the previous Australian standards.

Differently from the AASB, the FASB has not adopted the IFRS at full in 2005. Instead, since 2002 the FASB and the IASB have been implementing two joint convergence projects. While significant progress towards international convergence is expected to be made in the next few years, the volume and complexity of issues implied that many differences between IFRS and the US GAAP remained beyond January 2005. However, the remaining differences in the reporting of derivatives and hedging are not substantial enough to cause any significant disadvantages between future studies that may be based on either IFRS or on the US GAAP.

For example, the IFRS provides enough detail on how to recognise (identify) and measure (quantify) financial assets and liabilities; derivatives (including embedded derivatives); hedging instruments (derivative or non-derivative); and hedged items. Additionally, companies need to report hedging effectiveness, i.e., the degree to which changes in fair value or cash flows attributable to a hedged risk are offset by changes in the fair value or cash flows of the hedging instrument.

Also important for future research on corporate risk management, the IFRS requires more detailed information about executives' remuneration. Statement AASB 1046, operative since June 2004, requires companies to properly identify and quantify the following components of executives' remuneration: 1) primary benefits (cash salary, bonuses and profit-sharing); 2) post-employment benefits;
3) equity compensation (shares and options); 4) any other remuneration.

As far as interest rate risk hedging is concerned, statements IAS 39 / AASB 139 require risk identification and measurement in the following steps below:

- the portfolio of items to be hedged should be identified;

- analysis of the portfolio of items;

- decision about how much to hedge;

- decision about which interest rate to hedge;

- designation of hedging instruments;

- effectiveness analysis of the hedging;

- periodical measurement of the change in the fair value of the hedged items;

- periodical measurement of the change in the fair value of the hedging instruments;

- identification of any hedging ineffectiveness.

It can be noticed that, in relation to the previous accounting standards, the IFRS provides substantial improvement on hedging reporting. An important point is that researchers will be able to have a clear idea of measurable risks faced by companies and how much of these risks are being hedged with financial or nonfinancial instruments.

Therefore, future research will benefit from the availability of "hedge ratio" of each hedged risk exposure in a given company. As shown before, the appropriate measurement of the "hedge ratio" is important for the robustness of empirical analysis of the demand for hedging, in the sense of correctly identifying which factors drive the corporate use of hedging instruments to manage different risk exposures.

Table 6 International Financial Reporting Standards

\begin{tabular}{l|l|l|c}
\multicolumn{1}{c|}{ Statement No. } & \multicolumn{1}{|c|}{ Statement Title } & \multicolumn{1}{c|}{$\begin{array}{c}\text { Issued Date } \\
\text { Operative Date }\end{array}$} \\
\hline AASB 1046 & Director and Executive Disclosures by Disclosing Entities & 2004 Jan & 2004 30 Jun \\
\hline AASB 1046A & Amendments to Accounting Standard AASB 1046 & 2004 Sept & [ending] 2004 1 Jul \\
\hline AASB 7 & Financial Instruments: Disclosures & $2005 \mathrm{Aug}$ & $20071 \mathrm{Jan}$ \\
\hline IAS 1 / AASB 101 & Presentation of Financial Statements & $2003 \mathrm{Dec} / 2004 \mathrm{July}$ & $20051 \mathrm{Jan}$ \\
\hline IAS 32 / AASB 132 & Financial Instruments: Disclosure and Presentation & $2003 \mathrm{Dec} / 2004 \mathrm{July}$ & $20051 \mathrm{Jan}$ \\
\hline IAS 39 / AASB 139 & Financial Instruments: Recognition and Measurement & $2003 \mathrm{Dec} / 2004 \mathrm{July}$ & $20051 \mathrm{Jan}$
\end{tabular}




\section{THE AUSTRALIAN DATA SET ON INTEREST RATE RISK HEDGING}

In order to analyse the corporate demand for interest rate risk hedging in Australia, two panel data sets are built based on financial information from SEP/ASX 300 companies $^{7}$, from 1998 to 2003.

The first panel data set contains financial information from 189 companies, which are classified into hedgers and non-hedgers. This data set is used to analyse the corporate decision to hedge interest rate risk. The second data set contains only interest rate risk hedging companies. This data set contains observations from 78 companies, with detailed information about the interest rate risk exposures being hedged. In fact, this study focuses on corporate interest rate risk hedging because interest rate risk exposures are the only financial risk exposures that can be properly measured given the information available in the annual reports of Australian companies. Although other risks such as foreign currency risk and commodity price risk are reported, they are not reported in enough detail to be associated with the financial derivative instruments used to hedge them. On the other hand, Australian companies do report detailed information about their interest risk exposures and about the interest rate derivatives used. Moreover, a previous survey by Benson and Oliver (2004 [4]) shows that interest-rate-risk management is relatively more important for Australian companies than the management of foreign currency and commodity price risks. A possible reason for this is that Australian companies tend to borrow money locally, so that most of the loans are in local currency.

Balance sheet data and stock price data were obtained from the ASPECT Financial data set and from the ASX Daily data set, provided by SIRCA ${ }^{8}$. Interest rate risk exposures and hedging information are manually collected from annual reports provided by Connect 4 .

Some exclusions were necessary from the original data set. Judge (2003 [33]), p.19) explains that most previous studies on hedging with derivatives restrict their analysis to the hedging activities of non-financial companies because financial firms are both users and providers of risk management products. However, in this study only financial institutions which provide interest rate risk instruments, such as banks, are excluded from the sample, so that financial institutions that do not provide them, such as insurers, are not excluded. Other companies were also excluded because there was not enough financial information about them, or because financial information was available only for a very limited number of years.

In order to create the first data set, which distinguishes companies that hedge interest rate risk from those which do not, all available annual reports from ASX 300 companies were examined. After the exclusions mentioned above, the final data set comprises 189 companies. Companies are then classified as "hedgers" if they report the use of interest rate derivative instruments and as "non-hedgers" if otherwise, or if they report that they do not use interest rate derivatives. Therefore, out of 189 companies, 108 companies are classified as hedgers and 81 companies are classified as non-hedgers. Finally, a binary variable is created (" 1 " for hedgers and " 0 " for non-hedgers) so that it can be used in a probit regression to analyse the decision to hedge interest rate risk.

Table 70 shows the summary statistics for the data set used to analyse the corporate decision to use interest rate derivatives. The variables in Table 7 are proxies that potentially explain this decision.

The second data set is used to analyse the extent of interest rate hedging. It comprises of 78 hedging companies compared to the 108 hedging companies in the first data set. The reason for this is that 30 hedging companies do not provide enough financial information so that interest rate exposures can be measured properly. Companies in this data set are able to report the value of their inter-

Table 7 - Summary Statistics - Hedgers and Non-Hedgers

\begin{tabular}{l|r|r|r|r|r|r} 
Variable $^{\mathbf{1 0}}$ & $\mathbf{N}$ & Mean & Median & \multicolumn{1}{c|}{ Max. } & \multicolumn{1}{c}{ Min. } & \multicolumn{1}{c}{ Skew. } \\
Ln Assets & 1102 & 19.471 & 19.884 & 25.900 & 10.030 & -3.595 \\
\hline Leverage & 1102 & 0.476 & 0.500 & 4.669 & 0.000 & 4.719 \\
\hline Ln Returns & 1102 & 0.029 & 0.000 & 4.994 & -2.940 & 1.013 \\
\hline Future Tax Benefit & 1102 & 0.015 & 0.007 & 0.173 & 0.000 & 2.644 \\
\hline R\&D & 1102 & 0.124 & 0.003 & 23.578 & 0.000 & 20.170 \\
\hline Cur. Ratio & 1102 & 3.014 & 1.420 & 133.489 & 0.014 & 9.630 \\
\hline Free Cash Flow & 1102 & -0.043 & -0.012 & 3.037 & -1.558 & 2.307 \\
\hline EPS & 1102 & 16.021 & 12.600 & 219.000 & -402.000 & -1.956
\end{tabular}

7 The SEP / ASX 300 index represented 91\% of the Australian market at June 30, 2002

8 Securities Industry Research Centre of Asia-Pacific (SIRCA) www.sirca.org.au

9 www.connect4.com.au. The University of New South Wales (UNSW) provides access to data sets from both SIRCA and Connect4 to UNSW students and researchers. 10 "LN ASSETS" is the logarithm of assets value, which proxies for company size; "LEVERAGE" is the ratio of total liabilities to total assets; "LN RETURNS" is the annual log return in share prices; "FUTURE TAX BENEFIT" is the ratio of future tax benefits to total assets; "RED" is the ratio of research and development expenditure to total assets; the "CUR. RATIO" is the ratio of current assets to current liabilities; "FREE CASH FLOW" is the ratio of free cash flow to total assets; and "EPS" are earnings per share. 
est bearing liabilities and the principal notional amounts of interest rate derivatives used to hedge interest rate risk associated to these liabilities. In addition, all these companies report a statement similar to the following:

The consolidated entity is exposed to changes in interest rates. The consolidated entity uses interest rate derivative financial instruments to hedge its interest rate exposure. Derivative financial instruments are not held for speculative purposes.

This means that these companies have identified their interest risk exposures and reported the use of interest rate derivatives for hedging purposes only.

Table 80 shows summary statistics for explanatory variables in the data set of interest rate hedging companies. This table contains two additional explanatory variables: the financial ratio, and the float ratio. In fact, information about these two variables was only available in annual reports of companies which report their interest rate risk hedging activities in detail. Australian companies have to report financial assets and liabilities in detail. In addition, companies have to report three types of debt: 1) floating-interest-rate debt; 2) fixed-interest-rate debt; and non-interest-rate-bearing debt. The financial ratio is the ratio of financial liabilities to financial assets. The float ratio is the ratio of floating-interest-rate debt to total interest rate bearing liabilities. This variable measures the floating-to-fixed mix of interest bearing liabilities before any effects from interest rate derivatives. Therefore, this variable is a proxy for ex-ante interest-rate-risk exposure.

The available data set makes it possible to observe the floating-to-fixed mix of interest-rate-risk-bearing liabilities both before and after hedging with interest rate derivatives. Figure 10 shows the float ratio before hedging (ex-ante floating-to-fix mix) from 1998 to 2003. It can

Table 8 Summary Statistics - Interest Rate Hedging Companies

\begin{tabular}{l|r|r|r|r|r|r} 
Variable & N & Mean & Median & Max. & Min. & Skew. \\
Ln Assets & 465 & 20.33 & 20.58 & 23.55 & 14.39 & -5.71 \\
\hline Leverage & 458 & 0.51 & 0.51 & 0.99 & 0.07 & 0.03 \\
\hline Financial Ratio & 424 & 4.22 & 2.20 & 70.84 & 0.11 & 5.75 \\
\hline Float Ratio & 422 & 0.74 & 0.88 & 1.00 & 0.00 & -0.95 \\
\hline Ln Returns & 465 & 0.04 & 0.03 & 4.99 & -2.94 & 2.08 \\
\hline Future Tax Benefit & 458 & 0.02 & 0.01 & 0.08 & 0.00 & 1.28 \\
\hline R\&D & 465 & 0.09 & 0.00 & 12.41 & 0.00 & 11.96 \\
\hline Cur. Ratio & 458 & 1.43 & 1.30 & 8.70 & 0.01 & 2.26 \\
\hline Free Cash Flow & 458 & -0.01 & -0.01 & 3.04 & -0.96 & 11.12 \\
\hline EPS & 465 & 20.28 & 16.70 & 162.80 & -174.00 & -0.63
\end{tabular}

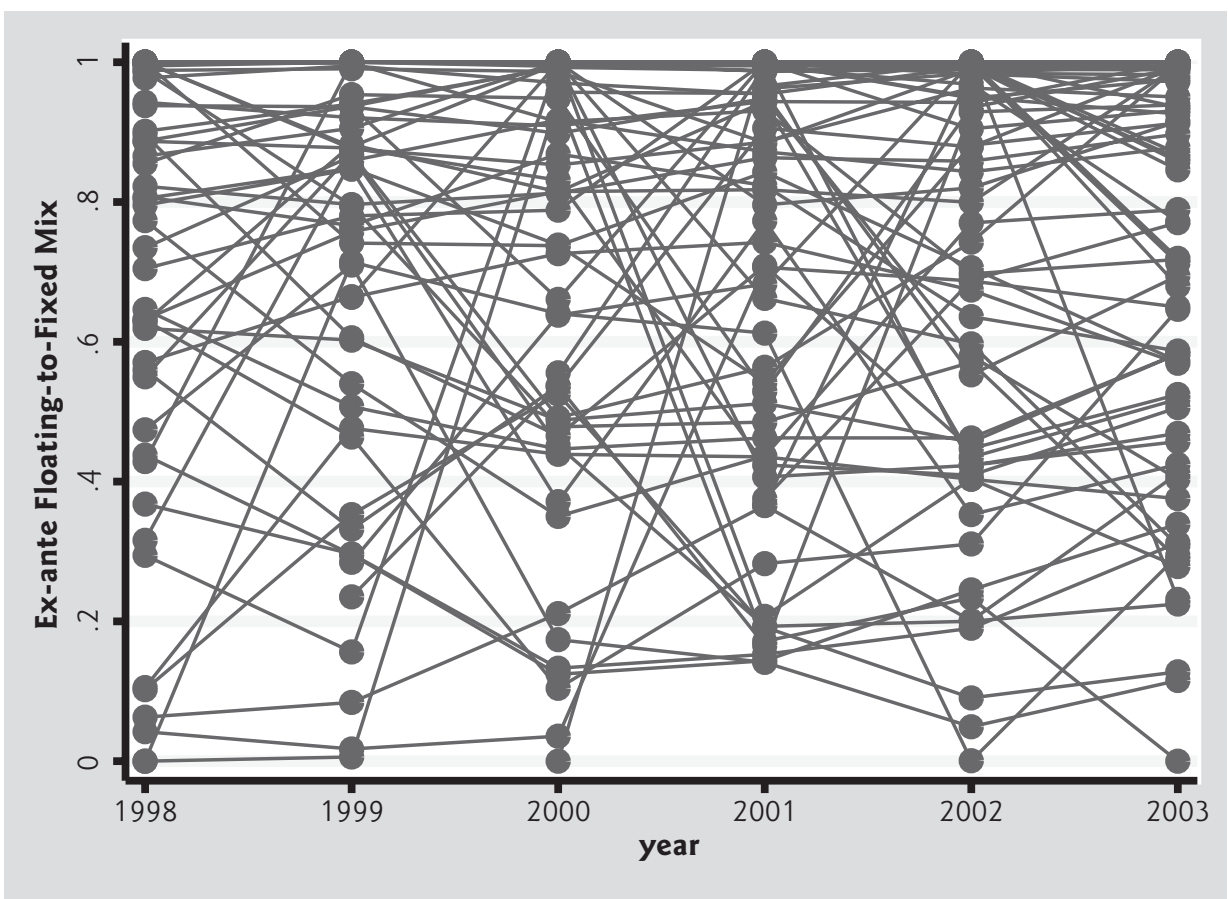

Figure 1 Floating-to-Fixed Mix Before Hedging 
be noticed that in all years this ratio is spread between 0 and 1 , despite some concentration between 0.4 and 1 . However, Figure $2 \boldsymbol{O}$ shows an important effect of interest-rate-risk hedging on this floating-to-fixed mix. Figure 2 shows that after hedging the floating-to-fixed mix is very concentrated between 0 and 0.5 . Moreover, it also shows that this mix does not vary much within companies from year to year. An important conclusion is that companies use interest-rate derivatives to continuously adjust their target floating-to-fixed mixes. Empirical results in this paper show that the ex-ante floating-to-fixed mix is one of the very significant variables explaining the corporate demand for interest-rate-risk hedging.

Table 8 also shows that interest rate hedging companies have on average a float ratio of 0.74 , which means that on average $74 \%$ of their interest bearing liabilities are indexed to a floating interest rate. A median float ratio of 0.88 means that $50 \%$ of the companies have a float ratio of at least $88 \%$.
The mean leverage and the median leverage are both approximately 0.51 , so that companies's total liabilities are on average $51 \%$ of their assets. The financial ratio (financial assets to financial liabilities) is on average 4.22 , but the median much lower, 2.20. Additionally, the current ratio (current assets to current liabilities) is on average only ${ }^{11} 1.40$, and its median is 1.30 . Free cash flow is on average approximately zero.

Table 8 shows that future tax benefits are on average equivalent to $2 \%$ of the company's asset value. This is the tax benefit from tax losses, which can be carried forward indefinitely by Australian companies. However, companies need to have positive results to make use of tax benefits. Therefore, it is expected that firms with large amounts of future tax benefits would hedge more to insure they have better chances of obtaining positive results.

\section{EMPIRICAL RESULTS}

\subsection{Probit Regression - The Decision to Use Interest Rate Derivatives}

Table 9 shows the results for the probit regression model used to analyse the corporate decision to hedge interest rate risk. In this regression analysis, however, a single year regression is used instead of a panel regression, using six-year data. The reason for this that a panel probit re- gression assumes that the decision to hedge in each year is independent from the decision to hedge in previous year.

Since this assumption is not realistic in this case, a single year probit regression is more appropriate. Therefore, Table $9-$ shows the results obtained by using data from 1998 (regressions with data from other years also provide similar results).

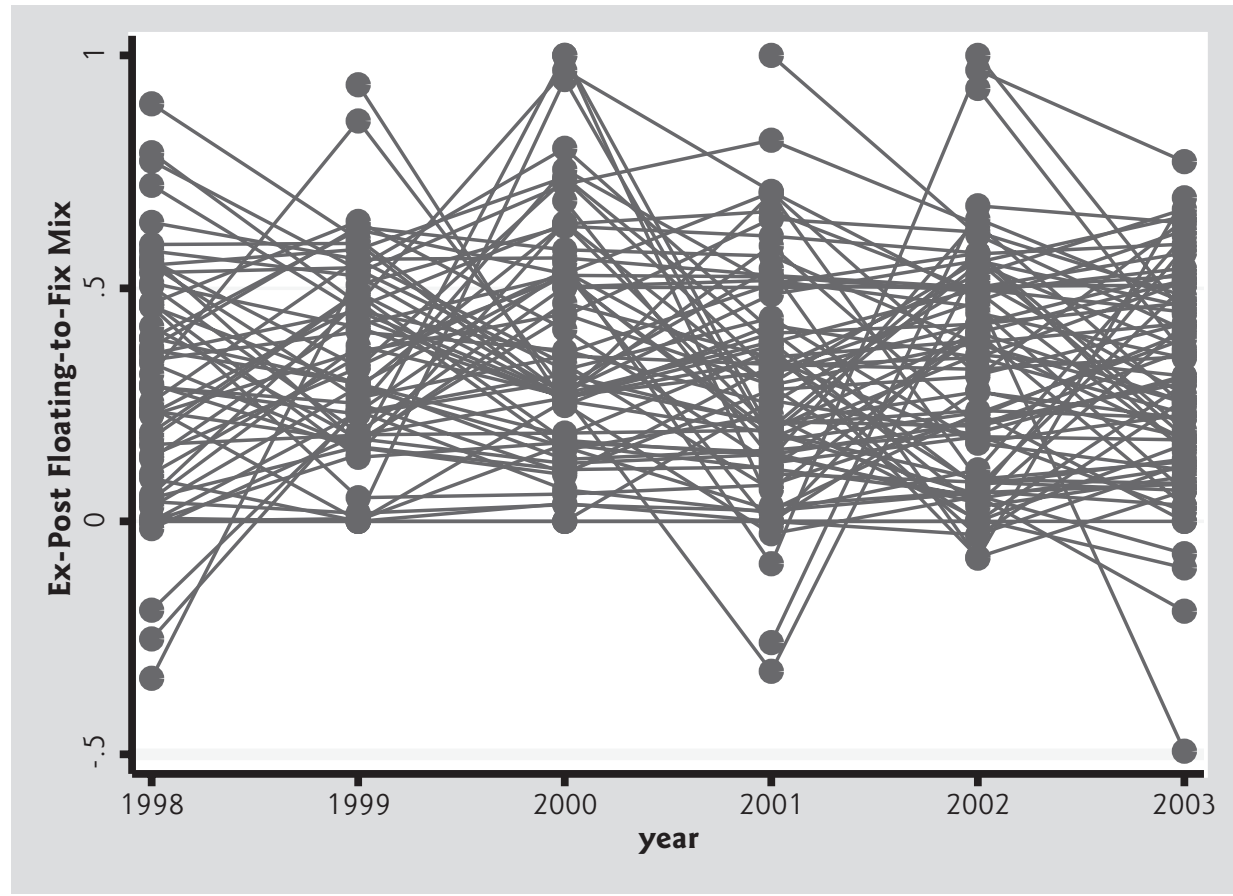

Figure 2 || Floating-to-Fixed Mix After Hedging

11 The current ratio is an indication of the company's ability to meet short-term debt obligations. If the current ratio is more than 2 , then the company is generally considered to have good short-term financial strength. 
Table 9 || Probit Regression Results - The Decision to Hedge Interest Rate Risk

\begin{tabular}{l|c|c} 
Regressor & Probit Estimate & (p-value) \\
Constant & -7.4540 & $(0.000)$ \\
\hline Ln Assets & 0.4011 & $(0.000)$ \\
\hline Leverage & -0.0381 & $(0.853)$ \\
\hline Ln Returns & 0.3066 & $(0.343)$ \\
\hline Future Tax Benefit & -5.0242 & $(0.324)$ \\
\hline R\&D & -0.0537 & $(0.216)$ \\
\hline Cur. Ratio & -0.0112 & $(0.233)$ \\
\hline Free Cash Flow & 0.7425 & $(0.233)$ \\
\hline EPS & 0.0037 & $(0.425)$
\end{tabular}

The dependent variable assumes value " 1 " if the company hedges interest rate risk with derivatives and " 0 " otherwise. The results show that company size is the only significant significant factor explaining the decision to hedge with interest rate derivatives.

This result reinforces the relevance of economies of scale in the decision to hedge with interest rate derivatives in Australia. The following section shows the analysis of the decision of how much hedge with interest rate derivatives.

\subsection{Empirical Results on the Extent of Interest Rate Risk Hedging}

Table $10 \oslash$ shows the estimation results for the extent to which companies hedge their interest rate risk exposures with derivatives. The data set used contains annual observations from 78 companies, from 1998 to 2003. Table 10 also shows 6 different model specifications (model 1 to model 6), obtained from different combinations of explanatory variables. The values in parentheses under the estimates are the $p$-values for those estimates. The correlation matrix for the explanatory variables in this data set is given by Table.1. The values in this correlation matrix show us that multicollinearity is not a problem in this data set. Section B.3 of Appendix B provides plots of correlations between these explanatory variables.

All 6 models were estimated the two different dependent variables, as explained above: 1) "N. VALUE/ASSETS" 12 , the notional value of derivatives divided by asset value, which is the dependent variable largely used in previous empirical studies; and 2) "HEDGE RATIO" which the ratio of the notional value of derivatives to interest bearing liabilities $^{13}$. The latter is intended to provide a better proxy for interest rate risk hedging activity, since its denominator gives a more appropriate measure of the company's interest rate risk exposure than company size. In fact, previous studies have only used company size as a proxy for risk exposure because of the lack of a more appropriate proxy. Diagnostic tests show that this panel data set has panel heteroskedasticity, contemporaneous correlation and serial correlation. Hence, OLS with PCSEs are used to estimate the parameters. As in Chapter 4, unit-specific dummies are included to account for fixed-effects ${ }^{14}$.

Table 10 includes three additional industry dummy variables, which are significant in all model specifications ${ }^{15}$ : 1) "D_util", for the utility industry; 2) "D_fin", for the financial industry" ${ }^{16}$; and 3) "D_propt", for the property trust industry.

The results in Table 10 show that estimates can be quite different depending on the dependent variable used. For example, in Model 1 the estimates for the LEVERAGE and for FUTURE TAX BENEFIT are significant if we use the $\mathrm{N}$. VALUE/ASSETS as the dependent variable, but not if the dependent variable is the HEDGE RATIO. The estimates for the FLOAT RATIO in Model 1 are significant regardless the choice of dependent variable. However, the value of these estimates are quite different: 0.1434 when the dependent variable is the N. VALUE/ASSETS, and 0.6019 when the dependent variable is the HEDGE RATIO. Model 1 also shows that the estimates for the CONSTANT and for the FINANCIAL RATIO are very insignificant in both cases. For this reason, these explanatory variable are not included in models 2 to 6 .

It is important to note that the positive and significant estimate for LEVERAGE obtained using the dependent variable N. VALUE/ASSETS in Model 1 is a common result in previous studies. However, using the HEDGE RATIO the estimate for LEVERAGE is not significant. This comparison suggests that previous results would probably have obtained different estimated results if better proxies for the risk exposures had been available. In fact, if the "true" interestrate-risk exposure is an important factor behind interest-

$12 \mathrm{~N}$. VALUE/ASSETS is the abbreviation for the ratio of notional value of derivatives to assets. This is the dependent variable used in most previous studies to measure the extent of hedging with derivatives.

13 The $R^{2}$ was approximately 0.91 for all the regressions using the N. VALUE/ASSETS and 0.89 for all the regression using the HEDGE RATIO. The $R^{2}$ are relatively high due to the inclusion of many unit-specific dummies to the model.

14 Interestingly, fixed-effects regressions (not shown) provided very similar results, except for the fact that they are not able to provide estimates for time-invariant dummies.

15 Dummy variables for the following industries were tested in Model 1, one at a time, and were all insignificant: Consumer Discretionary; Consumer Staples; Energy; HealthCare; Industrials; Information Technology; Materials; Telecommunications Services.

16 This excludes entities which provide financial derivative instruments, such as banks. 


\begin{tabular}{|c|c|c|c|c|c|c|c|c|c|c|c|c|c|c|c|}
\hline $\begin{array}{l}0 \\
\frac{0}{0} \\
\frac{0}{\Sigma} \\
\Sigma\end{array}$ & 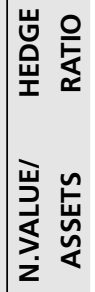 & & 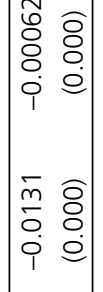 & 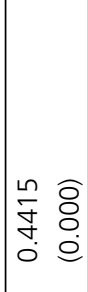 & & 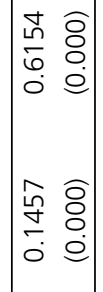 & 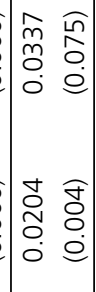 & 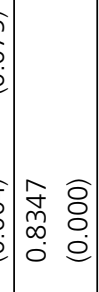 & 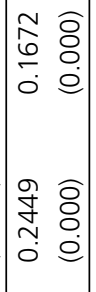 & 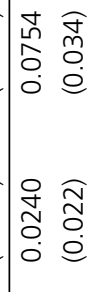 & $\begin{cases}0 & \frac{1}{0} \\
0 & 0 \\
0 & 0 \\
0 & 0 \\
0 & 0 \\
\infty & 0 \\
0 & 0 \\
0 & 0\end{cases}$ & & & & 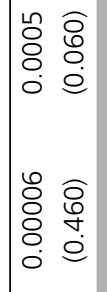 \\
\hline $\begin{array}{l}\frac{\operatorname{n}}{\mathbf{d}} \\
\frac{\mathrm{g}}{\mathrm{o}} \\
\Sigma\end{array}$ & 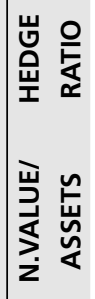 & & 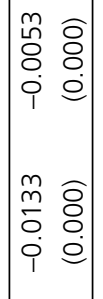 & \begin{tabular}{ll} 
& \\
$m$ & $\widehat{\partial}$ \\
\multirow{J}{*}{} & 8 \\
0 & 0
\end{tabular} & & $\left|\begin{array}{ll}0 & \widehat{o} \\
0 & 0 \\
0 & 0 \\
0 & 0 \\
0 & 0 \\
\infty & \widehat{o} \\
\multirow{2}{*}{} & \vdots \\
0 & 0\end{array}\right|$ & 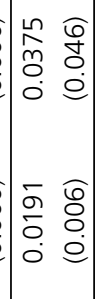 & 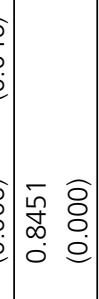 & 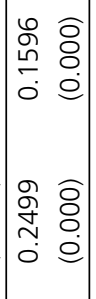 & 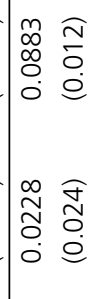 & 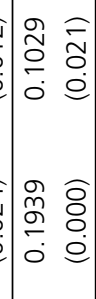 & & & 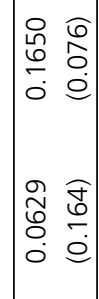 & \\
\hline $\begin{array}{l}\frac{\nabla}{d} \\
\frac{\delta}{8} \\
\grave{\Sigma}\end{array}$ & 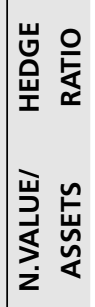 & & 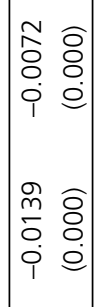 & 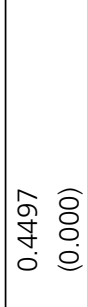 & & 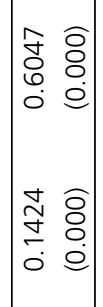 & 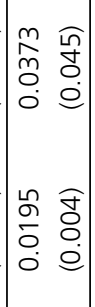 & 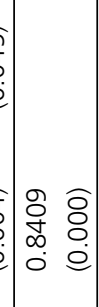 & 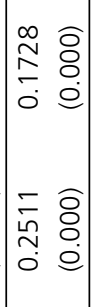 & 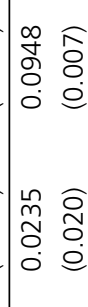 & 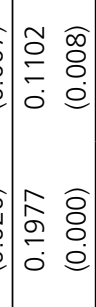 & & 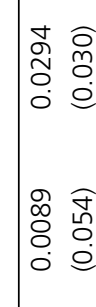 & & \\
\hline $\begin{array}{l}\frac{m}{d} \\
\frac{\delta}{\delta} \\
\Sigma\end{array}$ & 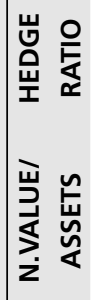 & & 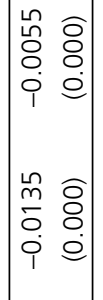 & 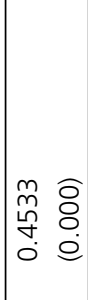 & & 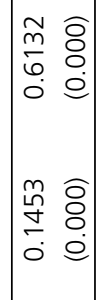 & 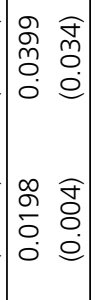 & 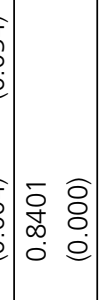 & 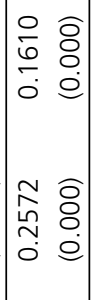 & 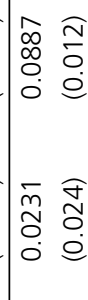 & 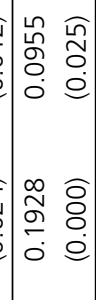 & 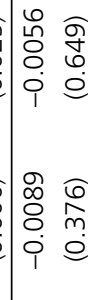 & & & \\
\hline $\begin{array}{l}\frac{N}{\Phi} \\
\frac{\Phi}{0} \\
\Sigma \\
\Sigma\end{array}$ & 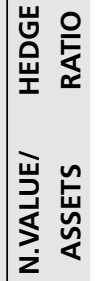 & & 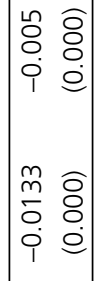 & $\mid \begin{array}{ll}\tilde{n} & \overline{8} \\
y & 0 \\
0 & 0\end{array}$ & & $\left|\begin{array}{ll}0 & \widehat{o} \\
0 & 0 \\
0 & 0 \\
0 & 0 \\
0 & 0 \\
0 & 0 \\
0 & \vdots \\
0 & 0 \\
0 & 0\end{array}\right|$ & 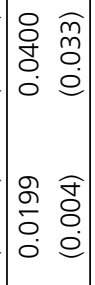 & $\mid \begin{array}{ll}9 & \widehat{o} \\
0 \\
0 & 0 \\
0 & \vdots \\
0 & \vdots\end{array}$ & $\left|\begin{array}{ll}0 & \widehat{o} \\
0 & 0 \\
0 & 0 \\
0 & 0 \\
n & 0 \\
0 & 0 \\
0 & 0 \\
0 & 0 \\
0 & 0\end{array}\right|$ & 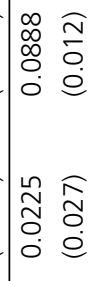 & 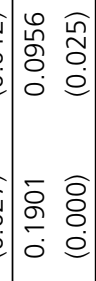 & & & & \\
\hline$\stackrel{\circ}{\Sigma}$ & 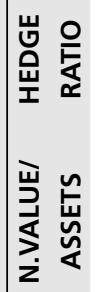 & 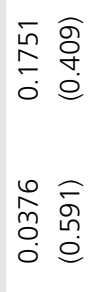 & 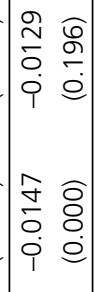 & 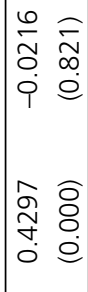 & 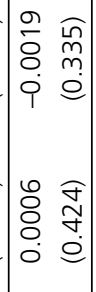 & 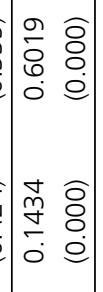 & 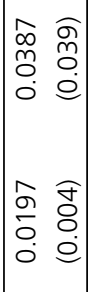 & 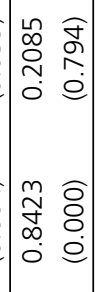 & 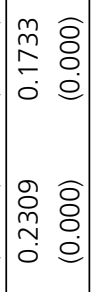 & 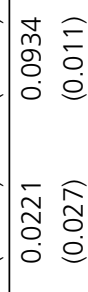 & 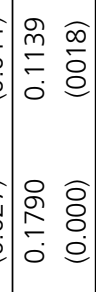 & & & & \\
\hline & 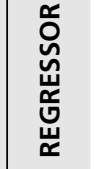 & $\begin{array}{l}\text { 主 } \\
\text { 点 } \\
\text { U }\end{array}$ & 㟔 & 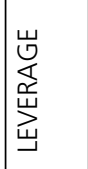 & 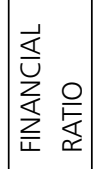 & 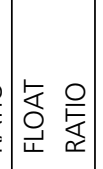 & 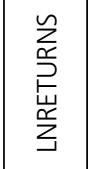 & 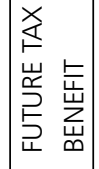 & 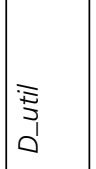 & 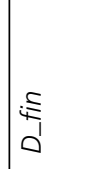 & $\begin{array}{l}\frac{a}{0} \\
0 \\
0 \\
0 \\
0\end{array}$ & $\underset{\propto}{\not}$ & 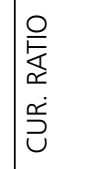 & 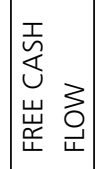 & $\tilde{\Perp}$ \\
\hline
\end{tabular}

rate-risk hedging, then mismeasurements of this factor may significantly affect the analysis of interest-rate-risk hedging demand. A detailed comparison of results from Model 2 is given below.
Model 2 includes only explanatory variables that are significant. We can see that when the dependent variable is the N. VALUE/ASSETS the most expressive explanatory variables are: the FUTURE TAX BENEFIT (0.8438) and 
LEVERAGE (0.4451). Also, in this case the estimate for the FLOAT RATIO is 0.1464 , which is even smaller than the estimates for the dummy variables $D \_u t i l(0.2426)$, and $D_{-}$ propt (0.1901). Finally, the remaining significant estimates are small in value: -0.0133 for the CONSTANT, 0.0199 for the LN RETURNS, and 0.0225 for $D \_$fin.

On the other hand, when the HEDGE RATIO is used as the dependent variable in Model 2 some estimates are very different. In this case, the most expressive estimate is that of the FLOAT RATIO (0.6136). This is a more reasonable result if we consider the previous analysis of this data set, in which the ex ante floatingto-fixed ratio and the ex post floatingto-fixed ratio are very different. Therefore, a consistent result should be the one in which the estimated coefficient for the FLOAT RATIO is quite expressive. The estimates for LEVERAGE and FUTURE TAX BENEFIT are highly insignificant and, therefore, are not included. The estimate for LN SIZE is almost zero (-0.005), implying that company size has almost no impact on the extent of hedging. The estimated coefficient of 0.0400 for the LN RETURNS means that more hedging is associated with higher returns in annual share prices. Finally, in this model specification the most important industry dummy variable is $D \_$util (0.1609), while $D_{\text {_ }}$ fin and $D \_p r o p t$ have less expressive estimates (0.0888 and 0.0956, respectively).

Models 3 to 6 include, one at a time, dummy variables for research and development expenses RED, for the current ratio CUR. RATIO, for free cash flow FREE CASH FLOW and for earnings per share EPS. At this point, the analysis should concentrate only on the estimated results provided my model specifications which use the HEDGE RATIO as the dependent variable, since it is believed to better capture the risk exposures being hedged with interest rate derivatives. Model 3 shows that the estimate for RED is very insignificant. Models 4 to 6 show significant estimated coefficients for the other dummy variables: 0.0294 for CUR. RATIO, 0.1650 for FREE CASH FLOW, and 0.0005 for EPS.
This results indicate that companies which hedge more are able to have a considerable higher level of free cash flow than companies that hedge less. The estimates for the current ratio and for EPS, although significant, are very small, implying that there is not much difference between the levels of current ratio and EPS of firms that hedge more as compared to to those levels in companies that hedge less.

In sum, the estimated results using the HEDGE RATIO in Models $2^{17}$ mean the following:

- size has a very small negative impact on the extent of hedging;

- leverage the Financial Ratio and Future Tax Benefit have no significant impact on the extent of hedging (Model 1) and therefore are not include in this model specification;

- both the Float Ratio and $D$ util the are the most relevant explanatory variables. This means that companies with higher proportion of floating interest risk debt or utility companies hedge more with interest derivative instruments;

- the significant and positive estimated coefficient for Ln Returns shows that higher annual share prices returns are positively associated with more interest rate hedging;

- the results from other industry dummy variable estimates show that companies from financial and property trust industries also hedge more than companies from other industries (except the utilities industry).

Models 3 to 6 also test the relevance of the following variables, one at a time: RED (research and development expenditures), CURRENT RATIO, FREE CASH FLOW and EPS. The results show that the estimated coefficient for RED is insignificant. The estimated results for the other dummies are significant, but only the estimated coefficient for free cash flow is expressive.

\section{CONCLUSION}

This study provides new relevant results for corporate interest-rate-risk management with derivatives. It shows that the measurement of financial risk exposures being hedged is crucial to the robustness of the empirical analysis of hedging demand. The paper shows how previous studies were limited in their ability to measure risk exposures due to limitations on financial reporting. However, reporting accounting standards specific to Australian corporations make it possible to properly identify and quantify interestrate-risk exposures so that adequate proxy variables can be used in this study. In fact, as far as we are aware, this is the first empirical study to measure the floating-to-fixed mix of interest-rate-risk-bearing liabilities. This measurement makes it possible to build an explanatory variable based on the ratio of the notional value of derivatives to interestrate-risk-bearing liabilities. Previous studies, on the other hand have used a dependent variable based on the ratio of the notional amount of derivatives to asset value, although most of them recognize that asset value is not an appropriate proxy for the hedged risk exposures.

The results show how some estimates are very different depending on the dependent variable used. If the dependent variable is the ratio of principal notional amount of derivatives to company size then the results show a significance of leverage, which is a common result in previous studies which use this dependent variable. How-

17 Model 2 was estimated with year dummy variables (from 1999 to 2003), which had all insignificant estimates. All other models were estimated with and without year dummies, but they generated very similar results. Year dummies had insignificant estimates in all cases. Models 1 and 3-7 show estimated results obtained without year dummies. 
ever, leverage is not significant if the dependent variable is the ratio of the principal notional amount of derivatives to interest-rate-risk-bearing liabilities. This result makes sense because leverage (e.g., total liabilities to total assets) does not give precise information about the firm's interest-rate-risk exposure. This exposure depends on the floating-to-fixed mix in interest-rate-riskbering part of liabilities and not on the total value of liabilities. The empirical results show the significant importance of the proportion of floating-interest-raterisk debt. The rationale is that firms have stable risk tolerances which determine their target floating-to-fixed mix of interest-rate-riskbearing liabilities. Therefore, how much firms will hedge depends on how much the current floating-to-fix mix defers from the target one. This study also finds significant relations of interest-rate-risk hedging with company size, floating-interest-rate debt ratio, annual log returns, future tax benefits, and company industry type (utilities and non-banking financial institutions).

Finally, future research will benefit from more detailed hedging reporting due to the recent changes implemented by the International Financial Reporting System (IFRS), whose hedging reporting requirements became operative in January 2005. Under the IFRS, financial reports will provide a detailed measurement of corporate risk exposures and financial and non-financial instruments used to hedge them. This will enable future research to obtain a more robust empirical analysis of the driving factors behind corporate risk management.

\section{Referências}

[1] ALLAYANNIS, Y:; OFEK, E. Exchange Rate Exposure, Hedging, and the Use of Foreign Currency Derivatives, Journal of International Money and Finance, 20, pp: 273296, 2001.

[2] BARTRAM, S. The Interest Rate Exposure of Nonfinancial Corporations, Economics Working Paper Archive EconWPA, 2001.

[3] — - BROWN, G.; FEHLE, F. International Evidence on Financial Derivatives Usage, AFA 2004 San Diego Meetings; EFA 2003 Glasgow Meetings, 2004.

[4] BENSON, K.; OLIVER, B. Management Motivation for Using Financial Derivatives in Australia, Australian Journal of Management, 29(2), pp. 225$242,2004$.

[5] BERKMAN, H.; BRADBURY, M.; HANCOCK, P.; INNES, C. Derivative Financial Instrument Use in Australia, Accounting and Finance, 42, pp. $97-$ $109,2002$.

[6] BERKMAN, H.; BRADBURY, M. Empirical Evidence on the Corporate Use of Derivatives, Financial Management, 25, pp. 5-13, 1996.

[7] BLOCK, S.; GALLAGHER, T. The Use of Interest Rate Futures and Options by Corporate Financial Managers, Financial Management, 15(3), pp. 73-78, 1986.

[8] BODNAR, G.; HAYT, G.; MARSTON, R.; SMITHSON, C. Wharton Survey of Derivatives Usage by U.S. Non-Financial Firms, Financial Management, 24(2), pp. 104114, 1995.

[9] _ _ — ; MARSTON, R. 1998 Wharton Survey of Derivatives Usage by US Non-Financial Firms, Financial Management, 27(4), pp. 70-91, 1998.

[10] BOOTH, S.; SMITH, R.; STOLZ, R. The Use of Interest Futures by Financial Institutions, Journal of Bank Research, 15, pp. 15-20, 1984.

[11] BREEDEN, D.; VISWANATHAN, S. Why do firms hedge? An asymmetric information model, unpublished working paper, Fuqua School of Business, Duke University, 1998.

[12] COLQUITT, L; HOYT, R. Determinants of Corporate Hedging Behavior: Evidence from the Life Insurance Industry., The Journal of Risk and Insurance, 64(4), pp. 649-671, 1997.

[13] CUMMINS, J.; PHILLIPS, R.; STITH, S. Corporate Hedging in the Insurnce Industry: The Use of Financial Derivatives by U. S. Insurers, North American Actuarial Journal, 1, pp. 13-39, 1997.

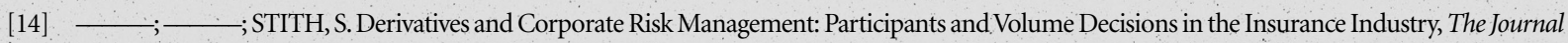
of Risk and Insurance, 68(1), pp. 51-91, 2001.

[15] DADALT, P.; GAY, G. D.; NAM J. Asymmetric Information and Corporate Derivatives Use, The Journal of Futures Markets, 22(3), pp. 241-267, 2002.

[16] DEMARZO, P. M.; DUFFIE, D. Corporate Incentives for Hedging and Hedge Accounting., The Review of Financial Studies, 8, pp. 743-771, 1995.

[17] DIAMOND, D. W. Debt Maturity Structure and Liquidity Risk, Quarterly Journal of Economics, 106, pp. 709-737, 1991.

[18] DOLDE, W. Hedging, Leverage, and Primitive Risk, The Journal of Financial Engineering, 41, pp. 19-37, 1995.

[19] FLANNERY, M. J. Asymmetric Information and Risky Debt Maturity Choice, Journal of Finance, 41, pp. 19-37, 1986.

[20] FENN, G.; POST, M.; SHARPE, S. Debt Maturity and the Use of Interest Rate Derivatives by Nonfinancial Firms, Working Paper, Capital Markets Section, Board of Governors of the Federal Reserve, 2005.

[21] FOK, R. C. W., CARROLL, C; MING, C. C. Determinants of Corporate Hedging and Derivatives: A Revisit, Journal of Economics and Business, 49, pp. 569-585, 1997.

[22] FRANCIS, J.; STEPHAN, J. Characteristics of Hedging Firms: An Empirical Investigation, in Robert J. Schwartz and Clifford W. Smith, Jr., eds., Advanced Strategies in Financial Risk Management, (New York Institute of Finance, pp. 615-635,1993.

[23] FROOT, K. A.; SCHARFSTEIN D. S.; STEIN J. C. Risk Management: Coordinating Corporate Investment and Financing Policies, Journal of Finance, 48(5), pp. 1629-1658, 1993.

[24] GAY, G. D.; NAM, J. The Underinvestment Problem and Corporate Derivatives Use, Financial Management, 27(4), pp. 53-69, 1998. 
[25] GECZY, C.; MINTON, M.; SCHRAND, C. Why Firms Use Currency Derivatives, Journal of Finance, 52, pp. 1323-1354, 1997.

[26] GRAHAM, J.; ROGERS, D. Do Firms Hedge in Response to Tax Incentives?, The Journal of Finance, 57(2), pp. 815-839, 2002.

[27] — - SMITH, C. Tax Incentives to Hedge.; The Journal of Finance, 54(6), pp. 2241-2262, 1999.

[28] GUAY, W.; KOTHARI, S. How Much do Firms Hedge with Derivatives, Journal of Financial Economics, 70,pp. 423-461, 2003.

[29] HAUSHALTER, G. Financing Policy, Basis Risk, and Corporate Hedging: Evidence from Oil and Gas Producers, The Journal of Finance, 55, pp. $107-152,2000$.

[30] HENTSCHEL, L.; KOTHARI, S. P. Are Corporations Reducing or Taking Risks with Derivatives?, Journal of Financial and Quantitative Analysis, 36(1), pp. 65-85, 2001.

[31] HOWTON, S.; PERFECT S. Currency and Interest-rate Derivatives Use in US Firms, Financial Management, 27, pp. 111-121, 1998

[32] JENSEN, M.; MECKLING, W. Theory of the Firm: Managerial Behavior, Agency Costs and Ownership Structure, Journal of Financial Economics, 3(4), pp. 305-360, 1976.

[33] JUDGE;A. Why Do Firms Hedge? A Review of the Evidence., Discussion Paper (Economics), No. 108, Middlesex University Business School, 2003.

[34] LELAND, H. Agency Costs, Risk Management, and Capital Structure, The Journal of Finance, 53(4), pp. 1213-1243, 1998.

[35] EINTNER, J. The Valuation of Risk Assets and the Selection of Risky Investments in Stock Portfolios and Capital Budgets, Review of Economics and Statistics, 48(1), pp. 13-37, 1965.

[36] LOOKMAN, A. Does Hedging Increase Firm Value? Evidence From Oil and Gas Producing Firms, Working Paper, Tepper School of Business, Carnegie Mellon University, 2004.

[37] MAYERS, S.; MAJLUF, N. Corporate Financing and Investment Decisions when Firms Have Informantion that Investors Do Not Have., Journal of Financial Economics, 3, pp. 187-221, 1984.

[38] MAYERS, D.; SMITH, C. On the Corporate Demand for Insurance: Evidence from the Reinsurance Market, Journal of Business; 54(1), pp. 19-40, 1990.

[39]. MIAN, S. Evidence on Corporate Hedging Policy, The Journal of Financial and Quantitative Analysis, 31 (3), pp. 419-439, 1996.

[40] MODIGLIANI, F.; MILLER, M. The Cost of Capital, Corporation Finance and the Theory of Investment, The American Economic Review, 48(3), pp. 261-92, 1958 .

[41] — _ MILLER, M. Corporate Income Taxes and the Cost of Capital: A Correction, The American Economic Review, 53(3), pp. 433-443, 1963.

[42] NANCE, D.; SMITH, C.; Smithson, C. On the Determinants of Corporate Hedging, The Journal of Finance, 48(1), pp. 267-284, 1993.

[43] NGUYEN, H.; FAFF R. On the Determinants of Derivative Usage by Australian Companies, Australian Journal of Management, 27(1); pp. 1-24, 2002.

[44] — FAFF R. Further Evidence on the Corporate Use of Derivatives in Australia: The Case of Foreign Currency and Interest Rate Instruments, Australian Journal of Management, 28(3), pp. 307-317, 2003.

[45] PURNANANDAM, A. Financial Distress and Corporate Risk Management: Theory and Evidence, Working Paper, year.

[46] SAMANT; A. An Empirical Study of Interest Rate Swap Usage by Nonfinancial Corporate Business, Journal of Financial Services Research, 10, pp. 43-57, 1996.

[47] SAUNDERS, K. T. The interest rate swap: Theory and evidence, Journal of Corporate Finance, 5, pp. 55-78, 1999.

[48] SCHRAND, C.; UNAL, H. Hedging and Coordinated Risk Management: Evidence from Thrift Convertions, Journal of Finance, 53, pp. 979-1013, 1998.

[49] SMITH, C.; STULZ, R. The Determinants of Firm's Hedging Policies, The Journal of Financial and Quantitative Analysis, 20(4), pp. $391-405,1985$.

[50] STULZ, R. Optimal Hedging Policies, Journal of Financial and Quantitative Analysis, 19, pp. 127-140, 1984.

[51] TITMAN, S. Interest Rate Swaps and Corporate Financing Choices, Journal of Finance, 47, pp. 1503-1516, 1992.

[52] TUFANO, P. Who Manages Risk? An Empirical Examination of Risk Managemente Practices in the Gold Mining Industry., The Journal of Finance, 32,pp. 1097-1137, 1996.

[53] VISVANATHAN, G. Who uses interest rate swaps? A cross-sectional analysis, Journal of Accounting, 13(3), pp. 173-200, 1998.

[54] Wall, L. D. Interest Rate Swaps in an Agency Theoretic-Model with Uncertain Interest Rates, ournal of Banking and Finance, 13, pp. $261-270,1989$.

[55] WARNER, J. Bankrupt Costs: Some Evidence, The Journal of Finance, 32(2), pp. 337347, 1977.

[56] WYSOCKI, P. Determinants of Foreign Exchange Derivatives Use by U. S. Corporations: An Empirical Investigation, Working paper, Simon School of Business, University of Rochester, 1995.

\section{NOTA - Endereço dos autores}

Universidade de São Paulo

Faculdade de Economia, Administração e Contabilidade Departamento de Contabilidade e Atuária

Av. Prof. Luciano Gualberto, 908 - FEA 3 - Cidade Universitária

São Paulo - SP

05508-900
University of New South Wales - UNSW

School of Actuarial Studies

2052 - Sydney - NSW

Australia 


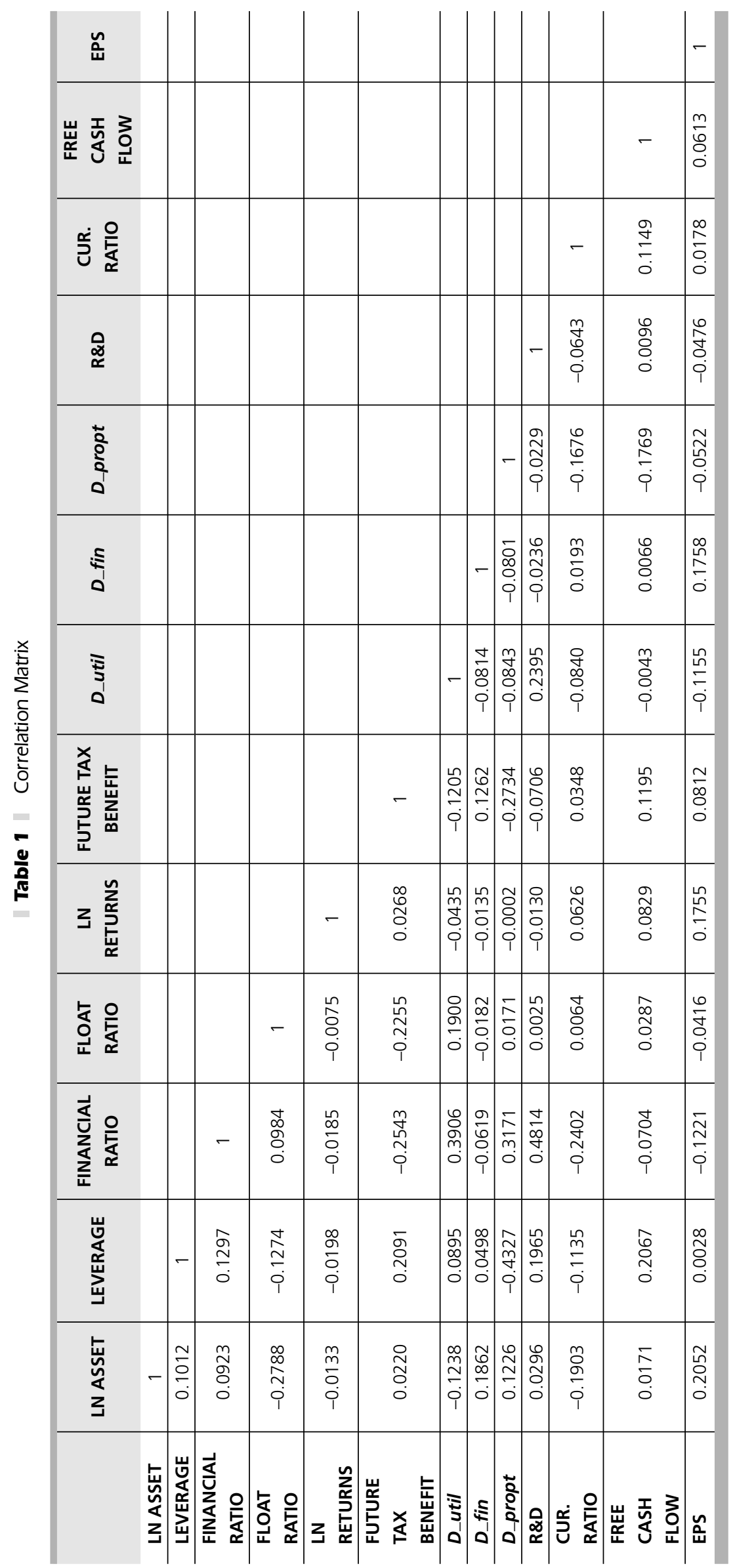

